\title{
The Quest for Standard Tests in Prioritizing Water Use Rights in Ethiopia: Reasonable Use, Beneficial Use or 'Beyond'
}

Zbelo Haileslassie Embaye *

\begin{abstract}
The use of water is a basic and universal human right while the right to use water is one of the most contested rights. There are common problems and debates in relation to setting the order of priority to promote equitable utilization aligned with equitable allocation under water resources governance. This article examines different literature, theories, laws and policies to search the standard tests. There are priorities related to conflicting interests. Moreover, there are problems of depletion, pollution, water grabbing, wastage of water, and water crisis that are attributable to lack of comprehensive regulations, or confusions in putting policy options. The regulatory tools lack clarity and sufficiency with regard to the incorporation of standard tests. There is thus the need for a relatively exhaustive order of priorities that embody human rights to water and other situational and policy justifications. The justifications are expected to reinforce the reasonablebeneficial use standard tests with due flexibility in re-ordering priorities where they are incompatible. The technical application of the standard tests in ordering priorities can control water grabbing and wastage of water. This requires policy options that are helpful to avoid water grabbing and water wastage thereby facilitating the attainment of the 'highest social and economic benefits'.
\end{abstract}

\section{Key terms}

Water use, reasonable use, beneficial use, priority, Ethiopia, standard test, water grabbing, water wastage

DOI http://dx.doi.org/10.4314/mlr.v10i1.6

\section{Introduction}

Water is one of the most essential, shared, and scarce natural resources that cause conflict and politically contested processes in relation to its use in international, national, and local settings. ${ }^{1}$ There are different understandings as

\footnotetext{
- Zbelo Haileslassie Embaye (BA in Sociology, LLB, LLM in Tax and Investment Laws); Lecturer at Mekelle University, School of Law. Email: zbelo40@gmail.com

${ }^{1}$ Mollinga P.P. (2008), 'Water, politics and development: Framing a political sociology of water resources management', Water Alternatives 1(1) pp, 7-23. See also, for example, Zemede Abebe et al. (2011), 'Water Futures: Assessing pathways, synergies \& trade offs in alleviating poverty through sustainable ecosystem services in Sub-Saharan Africa',
} 
to how the basic natural resources including air, land and water are governed. It is stated that "....air is unowned and unownable; land is as fully privatize-able as the law allows, and water is publicly owned but amenable to private rights of use or a usufruct, to give it its formal name". 2 However, water has been historically used, since the early civilizations, for different uses and tools; all societies had their own approaches in regulating access to water and conceptions of water rights. ${ }^{3}$ Most human rights activists argue that water law and water rights are highly associated with the universal human right instruments, and domestic laws adopt the human rights to water. ${ }^{4}$ Water rights can be widely defined and applied as "the right to use or enjoy the flowing water in a stream". 5 The proponents of the human rights approach to water rights suggest the need for 'innovative response' through separate water laws dealing with specific and technical issues even if it is a duplication of effort and wastage of resource. ${ }^{6}$ Although early water use laws solely regulated issues linked to navigational uses of shared water resources, ${ }^{7}$ later developments have necessitated the regulation of the non-navigational uses of shared water resources. ${ }^{8}$ This shows the need for 'substantive water law reforms' in general. ${ }^{9}$

Under different national laws, the types of water use and water use rights maybe defined differently. "Water law, and thus water rights, reflect economic,

Proceedings of the Situational Analysis 3 Ethiopia \& the River Awash Basin, RIPPLE Office, Addis Ababa (Ethiopia) \& the Water Futures Consortium, p, 20. Within River Awash Basin, “...Conflicts and disputes have also arisen as a result of irrigation development in the Middle and Lower Valleys that have displaced the 'Afar' grazing lands."

2 Joseph L. Sax, (2012) 'Reserved Public Rights in Water', Vermont Law Review, Vol. $36: 535$, p. 535.

${ }^{3}$ Stephen Hodgson (2006) Modern water rights, Theory and practice, Food and Agriculture Organization of the United Nations, FAO Legislative Study 92, p. 9.

${ }^{4}$ International Human Rights Law Clinic, (May 2013) The Human Right to Water Bill in California, University of California, Berkeley, School of Law, p, 6. Citing Legislative Intent-Assembly. Bill No. 685, ASSEM. J. 6817 (2011-2012 Reg. Sess.) The bill's legislative intent was "to create a state policy priority and direct state agencies to explicitly consider the human right to water within their relevant administrative processes, measures and actions."

5 Anthony Scott and Georgina Coustalin, (1995), 'The Evolution of Water Rights', Natural Resources Journal, Vol 36, pp, 821-979.

${ }^{6}$ International Human Rights Law Clinic, supra note 4, p. 1.

${ }^{7}$ Salman M. A. Salman, (2007). 'The Helsinki Rules, the UN Watercourses Convention and the Berlin Rules: Perspectives on International Water Law', Water Resources Development, Vol. 23, No. 4, pp 625-640.

${ }^{8}$ Id., p. 625.

${ }^{9}$ Stephen Hodgson, supra note 3, p. 1. 
social and cultural perceptions of water". ${ }^{10}$ The types of water uses in a given state may vary depending on existing situations of the state. In day-to-day parlance, water use right may be the right to use the water for consumptive and non-consumptive uses. Common uses of water from both types can be stated as the use of water for drinking, other domestic uses, irrigation of land and agricultural uses, industrial uses for electricity production other industrial uses, aquaculture, recreational uses, navigation and water transportation. Other uses may be stated impliedly as the common types of water uses and water use rights. $^{11}$

Under Ethiopian Water Law, water use is defined as the “... use of water for drinking, irrigation, industry, power generation, transport, animal husbandry, fishing, mining and uses of water for other purposes". ${ }^{12}$ The author mainly argues that clear and sufficient orders of priorities should be embodied under water policies and laws in establishing relative use rights because such clarity is necessary to avoid water use problems and to facilitate the attainment of the objectives of the law, i.e., "highest social and economic benefits". ${ }^{33}$ This article deals with the issue of whether the reasonable or beneficial use; or the combinations of both supported by other principles is/are incorporated under Ethiopia's policies and laws. It also examines whether the policy and legal instruments are clear and sufficient in embodying standard tests and orders of priorities. The article forwards potential options on how the standard tests may be used to prioritize orders of water use rights. It highlights the manner in which the standard ${ }^{14}$ tests avoid conflicting interests, 'water grabbing', and wastage of water with a view to facilitate the attainment of the law's objective. In doing so, it examines the interplay of different conceptual frameworks.

Among the potential standard tests, 'reasonable use' is one of the minimum standard tests referred to in this article because it strikes a balance of interests in the regulation of riparian rights and duties. ${ }^{15}$ The 'beneficial use' as one of the water use right restrictions under the prior appropriation doctrine is referred to

${ }^{10}$ Id., p. 4.

${ }^{11}$ Id., p.53. Citing, Article 65 of the Act 29/198, Spanish Water Law.

${ }^{12}$ FDRE Council of Ministers Ethiopian Water Resources Management Regulations No. 115/2005, Art 2(6).

13 FDRE Water Resources Management Proclamation 197/2000, para.1 of its preamble. The main objective of the proclamation is to reach the "highest social and economic benefits".

${ }^{14}$ A. Rambow et al. (1967) 'Methodology in Establishing Water Quality Standards', Journal (Water Pollution Control Federation), Vol. 39, No. 7, pp, 1155-1163. "A standard is proposed as an objective to be achieved or maintained immediately or within a short period from the time of its establishment. Setting of a standard implies consideration of the present limiting factors of technology, economics, and public policy."

${ }^{15}$ Anthony Scott and Georgina Coustalin, supra note 5, 871. 
in this article as additional standard test. ${ }^{16}$ The case laws of United States and English court cases are relevant since they define and characterize the standard tests. This has a direct relevance in setting out priorities supported by clear standard tests.

After describing and implicating the goals of the policy and features of the law to search for the standard tests, the clarity, specificity and sufficiency of the policies and laws (in setting out order of priorities) are examined against the potential standards. The possibilities on how efficient, effective, equitable, and sustainable water utilization may be assured within the ambit of natural resources' policies and laws is examined accordingly. This article envisions a new discourse on how these standard tests can be embodied in Ethiopian water policies and laws.

\section{Issues of Concern regarding Water Use Rights}

Water rights may emerge from a person's ownership of land, or use. ${ }^{17}$ The right "may be administered and controlled ... by a government agency or it may not be administered at all, and be subject to enforcement only in the courts". ${ }^{18}$ It can also be created indirectly through entering of contract between the right holder and potential user. ${ }^{19}$ The above commonly stated water use rights are subject to different problems. ${ }^{20}$ Most states are conscious to restore and protect the water resource from depletion and pollution. For the benefit of all, the water resources are destined to fall under the ownership of the public and state domains. In this case, Ethiopia's water resources are also designated to be owned and administered by the government in trust of the public. ${ }^{21}$ In legal terms, this concept is known as 'public trust doctrine'. ${ }^{22}$ This concept can be traced to sources such as the jurisprudential development of the US legal system. ${ }^{23}$ The

${ }^{16}$ Samuel C. Wiel (1915) 'What Is Beneficial Use of Water?', California Law Review, Vol. 3, No. 6, pp. 460-475.

${ }_{17}^{17}$ Anthony Scott and Georgina Coustalin, supra note 5, p. 821.

18 Ibid.

${ }^{19}$ Ibid.

${ }^{20}$ Stephen Hodgson, supra note 3, p. 53.

${ }^{21}$ See FDRE water resources management proclamation 197/2000, Art 5.

${ }^{22}$ Ralph W. Johnson, (1989) 'Water Pollution and the Public Trust Doctrine', Environmental Law, Vol. 19: pp, 485-491. Citing Cohen, (1970) 'The Constitution, the Public Trust Doctrine, and the Environment', UTAH L. REV. p, 388. “... the public trust doctrine originated from the widespread practice, from time immemorial, of using navigable waters as public highways and fishing grounds."

${ }^{23}$ Id citing 41 U.S. (16 Pet.) at 413 of the Martin v. Waddell case. The US Supreme Court ruled, "....shores, and rivers, and bays, and arms of the sea, and the land under them [were held] as a public trust for the benefit of the whole community, to be freely used by all for navigation and fishery, as well for shell-fish as floating fish.” 
doctrine has a direct implication on allocating water and prioritizing water use rights.

According to the public trust doctrine' primacy is given to public rights such as using water resource as 'critical resources' as compared to the private rights. ${ }^{24}$ It considers the state as a "... trustee and has the duty to properly manage natural resources for the benefit of present and future generations; and it indirectly embodies the key principles of environmental protection such as stewardship, communal responsibility, and sustainability". ${ }^{25}$ Water use rights and sustainable development are integrated through common principles.

However, policy options and commitment of a state may determine the version of sustainable development - i.e., the weaker or stronger version of sustainable development. Most states including the developed countries ... have "underpinned... the weak sustainability" ${ }^{26}$ This has a direct impact in the protection of the environment in general and the water resource in particular. In the author's opinion, states, including Ethiopia, are expected to be committed to the stronger version of sustainable development in order to achieve their obligation as a trustee in preserving public rights. Under 'weak' sustainability, the state ends up trading off one act against another act. ${ }^{27}$ This issue requires a separate research to examine the version (in the interpretation of sustainable development) that is adopted in Ethiopia.

Where a state pursues the weaker version of sustainable development, all users directly exploit the natural capital, as a base or a tool to accumulate the economic capital ${ }^{28}$ contrary to the public trust conferred upon the state to preserve the environment and the ecology. ${ }^{29}$ For instance, the socialist states have incorporated the 'rational use of natural resources' in an individual approach. ${ }^{30}$ Here, the 'rational use' of water resources may be taken as another

${ }^{24}$ Alexandra B. Klass and Ling-Yee Huang (September 2009) 'Restoring the Trust: Water

Resources and the Public Trust Doctrine', A Manual for Advocates, Center for

Progressive Reform, White Paper No. 908, p. 1.

${ }^{25}$ Id., p. 12.

${ }^{26}$ Andrea Ross (2009) 'Modern Interpretations of Sustainable Development, Economic Globalization and Ecological Localization: Socio-legal Perspectives', Journal of Law and Society, Wiley on behalf of Cardiff University, Vol. 36, No. 1, , pp. 32-54 citing A. Blowers, (1992) 'Planning a Sustainable Future: Problems, Principles and Prospects', Town and Country Planning 132, p. 61.

${ }^{27}$ Id., citing K. Bosselmann, (2008) 'The Principle of Sustainability- Transforming Law and Governance', p. 52.

${ }^{28}$ Ibid.

${ }^{29}$ Alexandra B. Klass and Ling-Yee Huang, supra note 26, p. 3.

30 Jana Klacková and Marian Sling (1978) 'The Principle of Rational Use of Natural Resources in the Theory of Optimal Planning', Eastern European Economics (Taylor \& Francis, Ltd.) Vol. 16, No. 4, pp. 3-23 
additional standard test. The weaker version only passes the 'capital stock'. ${ }^{31}$ This is directly linked with the types of water allocation systems applied in the state. ${ }^{32}$ Water use rights should thus reinforce the obligation of the state. It will have pivotal implication in prioritizing water use rights through clear standard tests.

\subsection{Water use right standard tests against water 'grabbing' and wastage}

Reasonable use is one of the minimum standard tests applied to strike the balance of interests in riparian rights and duties. ${ }^{33}$ Ethiopia's interest to incorporate the reasonable use test may be assessed from the policies and laws. The reasonable use test evolved from the English and United States case laws. Its application is widely seen in the $\mathrm{US}^{34}$, and can be traced back to the $1827 \mathrm{US}$ case law: Tyler $v$. Wilkinson. ${ }^{35}$ Its definition and application varies from state to state. $^{36}$

'Beneficial use' is another important standard test which redefines and applies the prior appropriation doctrine. It determines whether a certain use of water is recognized and protected by law against later appropriations. ${ }^{37}$ The justification for applying beneficial use as standard test is to prevent wastage of water resource. ${ }^{38}$ Prior appropriation is one of the common doctrines that allow

${ }^{31}$ Andrea Ross, supra note 26, p, 34. Citing D. Pearce, 3 (1993) Measuring Sustainable Development, Blue print, $\mathrm{p}, 15$. The natural capital is transferred to offset with the manmade capitals.

32 See Richard Harnsberger (Oct.1958) The Journal of Wild life Management, Vol. 22, No. 4, p. 452 Reviewing his own work Richard Harnsberger, (1958) 'The Law of Water Allocation in the Eastern United States'. In David Haber and Stephen W. Bergen (eds). The Ronald Press Company, New York, p, 643. In US water allocation was determined by sticking with either the riparian or prior appropriation, changes in water law, constitutional problems, economic factors, including protection of business investments, to be considered in providing for utilization and control of the water resource, and matters of administrative management.

${ }^{33}$ Anthony Scott and Georgina Coustalin, supra note 5, 871.

${ }^{34}$ Id., p. 872.

${ }^{35}$ Ibid citing Tyler Vs Wilkinson Case, 24 F. Cas. 472 (C.C.D.R.I. 1827).This case was instituted by mill owners over the right to use the flow of a river for mill power. The court ruled that all riparian have equal rights to use the water and that an upper proprietor cannot diminish the volume of the flowing river to the lower proprietor. Even though the court recognized that such an absolute right is challenging and may not be practical, it held the upper proprietor to make "reasonable use" of the water including consumptive withdrawals.

${ }^{36}$ Id., p, 872.The application of the reasonable use is contrasted in English and American case laws.

${ }^{37}$ Samuel C. Wiel, supra note 16, p. 460.

${ }^{38}$ Ibid. 
water use right with the maxim of 'first in time - first in right' ${ }^{39}$ It developed in response to scarcity of water in various regions. ${ }^{40}$ In its current application, it enshrines priority of use rights. The spirit of the doctrine is to give priority of water for beneficial uses.

The 1984 US Supreme Court decision in Colorado v. New Mexico ${ }^{41}$ case recognizes the need for setting out priority among water use rights and the need to have standard tests. The decision states the factors in the allocation of water. It reinforces the common manifestations of both standard tests in a single case.

\subsubsection{The role of standard tests in preventing water 'grabbing'}

Abuse of rights and capturing of water resources by dominant users against the rights of other users are among the most common water use problems. Despite the interconnectedness of water and land, much attention is given to land grabbing while the interconnected is ignored. ${ }^{42}$ According to Mehta, et al, grabbing is full of 'flawed legal procedures and political processes' that enable capture of water resources by focusing on 'the perceived illegitimate purpose of capturing'. ${ }^{43}$ The substantive water laws of any state are expected to put the legitimate right to capture water resource based on clear and sufficient legal standards.

Encompassing all grabbing issues, 'resource grabbing' is defined as a broad concept referring to the "appropriation of natural resources, including land and water, and the control of their associated uses and benefits, with or without the transfer of ownership, usually from poor and marginalized to powerful actors". 44 One of the major driving factors in 'land grabbing' is the intention of the grabber to have control of the water resource found above or below the land. ${ }^{45}$ It involves "contention between private-use rights and public claims of entitlement". 46

${ }^{39}$ Ibid

${ }^{40} \mathrm{Ibid}$

${ }^{41}$ See Colorado v. New Mexico 467 U.S. 310 (1984) available at:

$<$ https://supreme.justia.com/cases/federal/us/467/310/case.html $>$ last accessed on August 08/2016.

42 Jennifer Franco et al, (2013) 'The Global Politics of Water Grabbing', Third World Quarterly, 34:9, pp. 1651-1675.

43 Mehta, L et al (2012) 'Introduction to the Special Issue: Water grabbing? Focus on the (re)appropriation of finite water resources', Water Alternatives 5(2): Volume 5, Issue- 2, pp, 193-207 available at www.water-alternatives.org last visited

44 James Fairhead et al, (2012) 'Green Grabbing: a new appropriation of nature?' Journal of Peasant Studies, 39:2, pp. 237-261.

${ }^{45}$ Ibid.

${ }^{46}$ Joseph L, supra note 2, p. 535. 
'Land grabbing' is accompanied by the intent to grab water resource ${ }^{47}$ as well. According to Fairhead et al, first, 'land grabbing' is 'control grabbing' or it is the interest to capture the power of controlling the land, water and the green segment generally known as 'green grabbing'. ${ }^{48}$ This renders water use a 'politically contested process. ${ }^{49}$ Second, 'land grabbing' is defined by the scale of the land including the water being grabbed and the amount of capital invested to capture the land. ${ }^{50}$ Third, land grabbing involves multiple crises converging with accumulation of capital. And 'land grabbing' is accompanied by different 'dynamics of strategies' to capital accumulation. ${ }^{51}$ The effectiveness of water laws thus envisages their viability to curb both land and water captures.

There are key legal and non-legal approaches and contexts requiring the state to give concerns for 'land grabbing." "S2 "Stepping back, the key contexts today for 'land grabbing' appears to be the same for water grabbing" ${ }^{53}$ Prioritizing water use rights will also have an implication on prioritizing land use rights and vice versa. Applying the water approach to issues of grabbing enables a broader understanding on how the different types of grabbing operate and shows the impacts on use rights and other related issues. ${ }^{54}$

Water grabbing is defined as "... a situation where powerful actors are able to take control of, or reallocate to their own benefits, water resources already used by local communities". ${ }^{55}$ It is characterized by unequal relations of power and complexities. Powerful actors like investors use legal means as well as technical definitions to divert and profit away from the local communities. ${ }^{56}$ They are mostly done " ... by multinational companies and government agencies, dispossessing peasants and indigenous people and altering the environment". ${ }^{57}$ It may be manifested by 'externalisation of problems and costs' from the parties

${ }^{47}$ Borras, Jr. et al. (2012) 'Land grabbing in Latin America and the Caribbean', Journal of Peasant Studies 39(3-4): pp. 845-872. Cited in Mehta, L et al, supra note 45, p, 195.

${ }^{48}$ James Fairhead et al, supra note 44.

${ }^{49}$ Mollinga P. P, supra note 1, p, 10. Cited in Mehta, L. et al, supra note 43, p. 195.

${ }^{50} \mathrm{See}$, for example, World Bank, (2010) 'Rising global interest in farmland: Can it yield sustainable and equitable benefits?' Washington, DC: World Bank. See also, Oxfam, (2011) 'Land and power: The growing scandal surrounding the new wave of investments in land', Oxfam International Briefing Paper No, 51. Oxford

${ }^{51}$ Mehta, L et al, supra note 43, citing Borass et al. supra note 47.

${ }^{52}$ McMichael, P. (2012) 'The land grab and corporate food regime restructuring', Journal of Peasant Studies 39:3-4, pp. 681-701. Cited in Mehta, L. et al, p. 195.

${ }^{53}$ Mehta, L et al, supra note 45, p. 196.

${ }^{54}$ Ibid.

55 Ibid.

${ }^{56}$ Philip Woodhouse (2012) 'New investment, old challenges, Land deals and the Water Constraint in African Agriculture', The Journal of Peasant Studies, 39:3-4, pp, 777-794.

${ }^{57}$ Mehta, L. et al. supra note 43, p. 198. 
that cause them (i.e., investors and other big economic actors), to the communities. ${ }^{58}$ Whether the standard tests under the laws have prioritized water use rights (considering power factors and other complexities) determines the effectiveness of water laws.

There is an understanding that "it is difficult, if not impossible, to grab water without grabbing land" ${ }^{59}$ Even if there is an argument that water grabbing may exist without land grabbing; many authors contend that land and water are 'deeply entangled' where land grabbing is actually practiced. ${ }^{60}$ It is generally believed that "investors do not seek lands that do not have water for production in the first place". ${ }^{61}$ This shows the intersection between water laws, land laws and other related laws. Generally, water is a contested resource and access to water reflects power asymmetries, socioeconomic inequalities, and other distribution factors, such as the ownership of land etc. As water is finite, it has been subject to contestations that are rooted in power relations. ${ }^{62}$

\subsubsection{The role of water use right standards in minimizing wastage of water}

The correlative right and duty of the riparian right holders is manifested by the 'reasonable use' standard. ${ }^{63}$ The reasonable use enshrines the right to use naturally flowing water resource with a distinct channel. ${ }^{64}$ The right is also limited in relation to the number of the riparian right holders. ${ }^{65}$ The reasonable use is also referred to as 'ordinary use' in some court cases. ${ }^{66}$ Within the earlier developments of riparian rights, the right holders were only persons found in the

${ }^{58}$ Id., p. 201.

${ }^{59}$ Woodhouse, supra note 56, p, 781.

${ }^{60}$ Mehta, L et al, supra note 43, p. 196

61 Ibid.

${ }^{62}$ Mollinga P.P., supra note 1, p. 10.

${ }^{63}$ Anthony Scott and Georgina Coustalin, supra note 5, p, 871. citing English case (Embrey v. Owen) Exch. (1851), 155 Eng. Rep. 579. This case was the beginning of the reasonableuse regime of water law in England at the year 1851 because in that year a case was decided which made first mention of the concept of "reasonableness" in the context of water rights. See also Id, p, 873. This case was different from the US case law because there was a new emphasis on the rule that the law will not redress 'trivialities': "De minimis non curat lex" standing for "the law does not cure minimal damage." This exception was considered as infringing the riparian right holders.

${ }^{64}$ Id., p. 871. It is stated that the natural flow is meant to stand for unused flow. Unused flow is put for reasonable use and the reasonable use stands for the riparian right theory; but if it is continued flow or water that was used, it is related with prior-right theory.

${ }^{65}$ Id., p. 874. Citing Canadian Case (Miner v. Gilmour) 14 Eng. Rep. 861 (P.C. 1858). The riparian right holders were recognized and referred as "riparian rights doctrine". It was for the first time that the riparian right doctrine was recognized and applied the latter.

${ }^{66}$ Ibid. 
banks of the stream. ${ }^{67}$ Later developments have, however, shown the need to reasonably give the right to others without affecting prior riparian users. It can be inferred that allowing non-riparians to use the water resources may increase efficiency of water uses and avoid wastage. ${ }^{68}$ Rather than providing 'ordinary' users almost an absolute water use rights regardless of the effect it has on others, ${ }^{69}$ it was suggested that 'ordinary' use is, per se, 'reasonable. ${ }^{70}$

Water rights were fixed with land thereby causing wastage of water where riparians fail to utilize the natural water flow since non-use is not yet a cause to loss of right. This was taken as one of the disadvantages of the doctrine since other non-riparian water users were hindered from making beneficial uses even there are changes in the volume of the water resource. Under such circumstances, non-riparians seek access to usufructuary right to the water's flow. ${ }^{71}$ It is to be noted that there will be wastage of water if there is non-use in spite of access to non-riparians.

Other methods of right establishments were introduced by the non-riparians. Prescription is one among the methods. ${ }^{72}$ It is a method of acquiring a 'non possessory interest' in land through the continued use of the land but it is different from 'adverse possession' ${ }^{73}$ However, it may be rare if not impossible to get land uncontrolled and undeveloped by the first legal possessor or owner; state policies may clearly state land use rights or ownerships might be lost by non-use. For instance, the FDRE Rural Land Administration Proclamation states 'a rural land holder is obliged to use and protect his/her land. When the land gets

${ }_{68}^{67}$ Id., p. 821.

${ }^{68}$ Girma Tadesse, Peter G. McComick, Don Peden, Economic Importance and Environmental Challenges of the Awash River Basin to Ethiopia, proceedings of Water Rights and Related Water Supply Issues, pp. 258-269.

$<$ https://dspace.library.colostate.edu/bitstream/handle/10217/46435/111_Proceedings\%20 $2004 \% 20$ USCID $\% 20$ SLC $\% 20$ Taddese.pdf? sequence $=10 \&$ isAllowed $=y>$ last visited on Feb, 8/2016. The need for water management in the middle and lower basin of the Awash river, "is soil salinization, water contamination and increased waterborne diseases, and poor design leading to water loss through leakage and evaporation"

${ }^{69}$ Anthony Scott and Georgina Coustalin, supra note 5, p. 875.

${ }^{70}$ Ibid.

${ }^{71}$ Id., p. 849.

${ }^{72}$ Id., p. 827.

73 West's Encyclopedia of American Law, (ed) 2008, The Gale Group, Inc. Available at $<$ http://legal-dictionary.thefreedictionary.com/prescription>, accessed on January 15/2016. It defines .... "Prescription refers to a type of easement the right to use the property of another. It requires the use of the land to have been open, continuous, exclusive, and under claim of right for the appropriate statutory period. It differs from Adverse Possession in that adverse possession entails the acquisition of title to the property. 
damaged, the user of the land will lose the use right. ${ }^{74}$ This indirectly decreases the possibility of water wastage through non-use, evaporation or other human and natural factors. ${ }^{75}$ The loss of land use right with all accessible water resources may invite other potential users to use the land with its water resource.

The other legal issue that minimizes wastage of water resource is allowing adjacent persons, to the riparian land holders, to use water from the naturally flowing river. The FDRE Rural Land Administration Proclamation allows adjacent users to make use of water for irrigation purposes through construction of irrigation canals. They are allowed to cross the land of the riparian and use the water resource. ${ }^{76}$ The legal recognition of other users to use the water resource may have an advantage and disadvantage at the same time. Although the disadvantages may include inequity, inefficiency, pollution, depletion and captures $^{77}$, it is advantageous since it avoids wastage of water and enables efficient and effective utilization of water resources.

Characterizing the features and constituents of the reasonable use in a way to discourage wastage can be taken as another solution. ${ }^{78}$ From the legal perspective, in some cases reasonableness is tested through searching for malice intent or the damage it inflicts on others. ${ }^{79}$ For instance, the early reasonable use doctrine was associated with 'reasonable damage. ${ }^{80}$ Evidence proving unreasonable interference on domestic use is considered as unreasonable use. ${ }^{81}$ Domestic use is considered as 'ordinary-use' and it is the minimum right to all riparians to use the same water resource. ${ }^{82}$ However, reasonable test becomes

${ }_{75}^{74}$ FDRE Rural Land Administration Proclamation 456/2005, Art 10(1).

${ }^{75}$ Joseph L, supra note 2, p. 537.

${ }^{76}$ FDRE Rural Land Administration Proclamation 456/2005, Art 10(2).It puts the obligation on land holders to allow the construction of irrigation lines and other infrastructures by other users.

${ }^{77}$ Mehta, L et al, supra note 43.

78 Jeremiah Smith, (1917) 'Reasonable Use of One's Own Property as a Justification for Damage to a Neighbour,' Columbia Law Review, Vol. 17, No. 5, pp. 383-403

${ }^{79}$ Ernest W. Huffcut, (1904) 'Percolating Waters: The Rule of Reasonable User', The Yale Law Journal, Vol. 13, No. 5, pp, 222-227. “....In any case the test is the reasonableness of the interference with the natural flow or percolation. Malicious interference without benefit to the one interfering can never be regarded as reasonable."

${ }^{80}$ Anthony Scott and Georgina Coustalin, supra note 5, p. 873. "... This was because of a new emphasis on the rule that the law will not redress trivialities: 'de minimis non curat lex.'

${ }^{81}$ Ibid ".... This evidence could be the fact that the defendant had caused damage to another riparian user, that he had prevented an "ordinary user" from enjoying his domestic uses of the water, or that his use was unreasonable per se (such as a polluting use), any of which findings would routinely justify a finding against the defendant."

${ }^{82}$ Id., p. 875. 
subjective and full of discretion. ${ }^{83}$ The decision of the US Supreme Court in Colorado v. New Mexico, shows how reasonable use may be tested in balancing benefit against harm among users while at the same time considering other issues. $^{84}$

In considering New Mexico's exceptions to the Master's report, this Court held, inter alia, that the Master properly did not focus exclusively on the priority of uses along the river, and that other factors - such as waste, availability of reasonable conservation measures, and the balance of benefit and harm from diversion- could be considered in the apportionment calculus.

Reasonable use may be beyond the ordinary use and be against wastage. Meanwhile, water allocation need to consider wastage of water, sustainable conservation measures and the balance between harm and benefits. The reasonable standard test is broader. Some even stretch the reasonable use test to accommodate individual, social, environmental, economic, cultural and other different concerns related with public welfare. ${ }^{85}$ If water use does not cause pollution and depletion of the water resource itself, it is said to be reasonable use for the environmentalists. ${ }^{86}$ Likewise, if a specific use of any individual does not affect the right to recreation of the community, it is said to be reasonable use. $^{87}$

Wastage of water is unreasonable use where the said use does not consider the impact on the economic, social, cultural, and environmental needs of the

${ }^{83}$ Id., p, 877. “... Apart from this suggestion that flexibility may have been exercised in the definition of "ordinary" uses of the water to give protection to certain necessary uses, it is clear that by defining detrimental uses as "per se unreasonable"." The English courts had attempted to narrow the scope of their discretion while the Americans have carved out for themselves "a role as agents of the society's interest by enlarging the scope of their discretion."

${ }^{84}$ See Colorado v. New Mexico, 467 U.S. 310 (1984) available at $<$ https://supreme.justia.com/cases/federal/us/467/310/case.html $>$. Last accessed on August 08/2016

85 Joseph L. Sax, supra note 2, p, 536. Citing Article 10, section 2, of the California Constitution (CAL. CONST. art. 10, $\S 2$.) It states that “.... [T] he general welfare requires that the water resources of the State be put to beneficial use to the fullest extent of which they are capable and that the waste or unreasonable use or unreasonable method of use of water be prevented ... in the interest of the people and for the public welfare."

${ }^{86}$ See for example, Ralph W. Johnson supra note 24 , p. 498. It is recognized using water without having nonpoint water source pollution is considered as reasonable use; however, the reasonable use may not avoid pollution but through the application of the public trust doctrine.

${ }^{87}$ See, for example Philip C. Metzger, (March 1988), 'Protecting Social Values in Western Water Transfers', Journal (American Water Works Association), Water Marketing, Vol. 80 , No. 3, pp. 58-65. The protection to recreation is incorporated as the public's interest in water. 
majority. The overall point is that it may lead to an aggravated wastage where abusers mask themselves by the 'reasonable use' standard. Where its elements of the standard are not clearly and exhaustively articulated, the reasonable use test can be susceptible to abuse of rights ${ }^{88}$ thereby hindering the equitable, effective and efficient governance of water resources. The incorporation of a single standard test such as the reasonable use test may not thus be adequately effective unless it is narrowly and objectively construed.

The application of the beneficial use as a test also helps in preventing wastage of water in the course of its use by riparians and in addition to the riparian setting. ${ }^{89}$ As one of the general property rights, water right enshrines the right to abstract water at any chosen point of a river or any water resource destined as public domain. ${ }^{90}$ However, water rights are subject to limitations and the right holder may not waste public water. In a wider sense, "beneficial use is the limitation of the water right". ${ }^{91}$ The beneficial use test puts a limitation in order to discourage wastage of water by water users.

As shown in the US court case of Colorado v. New Mexico (stated above), wastage of water may be used as a factor in prioritizing use rights and allocating water for beneficial purposes. The following section examines the incorporation, clarity and sufficiency of standard tests under Ethiopian water policy and laws.

\section{Standard Tests of Prioritization under FDRE Water Policy and Water Laws}

There are different concerns in the prioritization of water use rights. The priority of water use right stated under the law may not be in conformity with the priorappropriation doctrine. ${ }^{92}$ However, any priority enshrines an 'objective basis' for allocating a limited water resource from the same source based on relative priorities. $^{93}$

The notion known as an 'out-of-priority' water use "appears on its face to be incongruent with the prior appropriation". ${ }^{94}$ Indeed, this notion violates the basic

${ }^{88}$ See, for example, Art 2(6) of Proclamation 197/2000. It states an illustrative definition of domestic use.

${ }^{89}$ Samuel C. Wiel, supra note 16, p. 462 . The beneficial use “....inquiry has been devoted to the 'duty of water,' whereby 'beneficial use' is expressed in scientific units namely the water is needed per acre of land or the acres irrigable by a unit of water."

90 See Marika Van Der Walt and Gerrit Piennar (2012) "The concept "beneficial use" as a limitation of the right to use water', Journal of South African Law, TSAR 2012-3, p, 422.

${ }^{91}$ Ibid.

${ }^{92}$ See Lawrence J. MacDonnell, (2005) 'Out-of-Priority Water Use: Adding Flexibility to the Water Appropriation System', Nebraska Law Review, Vol. 83:485, p, 485.

${ }^{93}$ Id., p, 487.

94 Ibid. 
prior appropriation principle since the latter appropriations were expected to remain behind all prior established uses unless there is excessive access of water. ${ }^{95}$ Ethiopian water law neither adopts the out of priority water use right approach nor has it incorporated clear and sufficient order of priorities supported by exclusive standards.

The 'out-of-priority' water use is grounded on the 'lack of injury standard'. ${ }^{96}$ Pursuant to this standard, consequent use will be accorded legal protection if other prior users "... continue unimpaired" or if prior users who are affected "are satisfactorily compensated in some manner" ${ }^{97}$ Therefore, the out of priority is different from the principle of priority in prior-appropriation doctrine, ${ }^{98}$ and it also varies from the order of priority solely established under any water law. The status of Ethiopia's water policy and laws with regard to standard tests are examined in the following subsections.

\subsection{Standard tests in the FDRE Water Policy}

Ethiopia's water policy states the country's annual surface runoff of close to 122 billion cubic meters of water excluding ground water. ${ }^{99}$ It also shows the uneven spatial distribution of water resources across the country. The policy, albeit inadequate, addresses the potential conflict of interest among the potential users. For instance, it impliedly seems to give priority to agricultural uses of water because it states that the use will continue as long as the agricultural output is more beneficial comparing with other types of water uses. ${ }^{100}$

The policy does not state who will be the potential prior water user even within the agricultural use if conflict of interest arises between the ordinary farmers basing their life on it and large scale investors who are involved in mechanized agricultural investments. ${ }^{101}$ The policy gives a priority of use for household consumption but other orders of use will follow the latter based on the "equitable and efficient socio-economic development criteria". ${ }^{102}$ The Policy states that performance on water development 'totally or individually' across the country are poor and the root causes are associated with "... the absence of a

95 Ibid.

${ }^{96}$ Id., p, 493.

${ }^{97}$ Ibid.

${ }^{98}$ Id., p. 485. Citing Irwin v. Phillips, 5 Cal. 140 (1855) “.... where courts in the western states have used the principle of first-in-time, first-in-right to determine water use rights."

99 FDRE, Ministry of Water resources, Ethiopian Water Resources Management Policy, (1999) Pp. 25. The policy has put the first objective of assuring food security, p. 4. See, the introduction part of the policy document.

${ }^{100}$ Id., p. 23. It states "Agriculture - based industrial development is the core element in the Federal economic development strategy."

101 Ibid.

${ }^{102}$ Id., p. 12, under the "General policies of water", Roll number 10, of section 2.1.1. 
well-defined, coherent policy and the lack of the required huge investment ..." on which the overall socio-economic development would base. ${ }^{103}$

On the contrary, the policy confirms that if the country's water resources are properly developed to use for irrigation, it predicts to get sufficient domestic production for consumption and make the 'agricultural surplus accessible' to market channels. ${ }^{104}$ It states the multifaceted problems due to lack of appropriate and 'comprehensive' water resources management policy; but it envisages implementing the principles by putting other options. ${ }^{105}$ It puts a direction on the need of 'priority schemes'. 106

In general, the policy states about water use but it does not clearly and adequately incorporate any solution if a conflict of interest arises between simultaneous applicants requesting for a permit of water use rights. Nor does it embody detailed order of priority in order to avoid the potential conflict of interest. Under the irrigation section of the policy document, it aspires to "develop a priority scheme based on food requirements, needs of the national economy, and requirement of raw materials and other needs". 107

Impliedly, the policy anticipates the potential conflict of water use rights. ${ }^{108}$ The promotion and benefits of agricultural investment vexed with local farmers' interest is discussed in various literature to show the dilemma of the policy and conflicts of interest. ${ }^{109}$ The Agricultural Development Strategy strengthens the need for "... increasing production of export crops and food ...". ${ }^{110}$ It accords first priority to the right to food, followed by the second priority regarding the needs of the national economy, and the "requirement of raw materials and other needs" in third order of priorities, even if there may be arguments to the contrary. ${ }^{111}$ Although due consideration of priorities, concerns and interests of

${ }^{103}$ Id., p, 36.No. 9 of Section 2.3.2.3. Even it has stated there is a need to "Establish water allocation and priority setting criteria based on harmonization of social equity, economic efficiency and environmental sustainability requirements."

${ }^{104} \mathrm{Id}$., p. 5, paragraph 7 of the introduction part of the policy.

105 Ibid.

${ }^{106}$ Id., p.35. No. 6 of Section 2.3.

${ }^{107}$ Ibid.

${ }^{108}$ See, for example, François Piguet, (2007) 'Complex Development-Induced Migration in the Afar Pastoral Area (North-East Ethiopia)', The Forced Migration \& Refugee Studies Program, The American University in Cairo, Egypt, p, 13. The current promotion of "private investment in irrigated agriculture, looking now to develop agro carburant, has also heightened conflicts."

109 Tom Lavers, (2012) 'Land grab' as development strategy? The political economy of agricultural investment in Ethiopia', The Journal of Peasant Studies, 39:1, pp, 105-132

${ }^{110}$ Id., p, 113.

${ }^{111}$ The FDRE Water Policy, supra note 99, p. 36. 
farmers would have enabled to create equitable sharing and to prevent conflicts over water use, there is no clear statement under the policy to foster priority. ${ }^{112}$

The Ethiopian water policy states general, unclear and insufficient stipulations on priority principles. It sets forth mutually nonexclusive and category based order of priorities. Unlike the Ethiopian Water Policy, the 1997 Water Policy of the Republic of South Africa clearly embodies two key policies; 'sustainability and equity'. It was clear and was adopted to promote social goals. The subsequent 1998 National Water Law implements these key principles. ${ }^{113}$

Power relations and power asymmetries of different users may bring inequitable utilization of water resources. ${ }^{114}$ The direct and indirect impact of Ethiopia's water policy ${ }^{115}$ on Food Security (which involves the availability and accessibility of water resources) deserve due attention. As a result of policies that fail to offer due attention to food security, the majority may be adversely affected by water shortage and drought. One of the challenges in securing social justice is thus associated with the problems of natural resource grabbing and the absence of distributive justice in natural resources. ${ }^{116}$

It is also contended that where the ownership of water is transferred from the community or customary right to state control, it is a means and an end to grabbing, corruption and inequitable governance of water resources. ${ }^{117}$ However, the potential difference between the nature and effect of grabbing among the developed, developing and the least developed countries is not clearly singled out. Even if the state is taken as the trustee of the public, it is always a dilemma to prioritize the policy options. ${ }^{118}$

It is also important to underline that implied priority is different from the priority right established through prior-appropriation because the definite time ("first-in-time, first-in-use") is used as a determinant factor to establish prior water use rights. ${ }^{119}$ In relation to irrigational uses, the policy is expected to enshrine the priority right in line with the constitutional mandate of securing the

\footnotetext{
${ }^{112}$ Mastewal Yami, (2016) 'Irrigation projects in Ethiopia: what can be done to enhance effectiveness under 'challenging contexts'?' International Journal of Sustainable Development \& World Ecology, 23:2, pp. 132-142.

${ }^{113}$ Hodgson, supra note 3, p, 27.

${ }^{114}$ Ibid.

115 See, for example, Gowing, J. (2003) 'Food security in sub-Saharan Africa: does water scarcity limit the options?', 3 Land and Water Resources Research 1.

${ }^{116}$ See, for example, Anna F. S. Russell, (2011). 'Incorporating social rights in development: transnational corporations and the right to water', International Journal of Law in Context, 7, pp. 1-30

${ }^{117}$ Mehta, L. et al. supra note 43, p. 195.

${ }^{118}$ Ibid.

${ }^{119}$ Compare the priority stated in the policy and in Samuel C. Wiel, supra note 16.
} 
well-being of individuals, public welfare, the right to development, equal access to opportunities and the progressive realization of socio-economic rights. ${ }^{120}$ The implied reading of the policy seems to give absolute right for irrigation uses even where the users may start using the water flow later than other nonirrigation users. ${ }^{121}$ However, it is to be noted that any interpretation of the policy in a manner that adversely affects the human right to water of the large population will be unconstitutional.

Where there is accommodation of public interest, the policy manifests reasonable use but not in the holistic and original conceptualization of the riparian doctrine. ${ }^{122}$ With regard to farming land, the Rural Land Administration Proclamation states that every peasant farmer engaged ".... in agriculture for a living shall be given rural land free of charge: is given the right to entitlement of land possessions or tenures..."123 On the contrary, the equitable distribution of benefits for farmers to irrigation purposes is constrained by 'land fragmentation' and 'landlessness'. ${ }^{124}$ For example, Piguet states that Agriculture Extension Programme (1999) contradicts with the then new 'Tendaho' dam to irrigate about 60,000 hectares in lower Awash Valley. ${ }^{125}$ The right to make use of the water was established immediately after the acquisition of land.

The policy does not expressly state order of priority if a potential conflict of use rights arises among the different categories of uses. ${ }^{126}$ However, by merely looking at the list of the use categories, one may say that the policy has impliedly given priority of use based on public merit. ${ }^{127}$ Such lack of clarity in Ethiopia's Water Policy with regard to prioritizing water use categories, is inconsistent with the law which -as discussed in Section 2.2- gives priority to domestic use over any other uses.

${ }^{120}$ See, The FDRE Constitution (1995) and read cumulatively Art 13(2), Art 43, Art 92 and the policy document.

${ }^{121}$ See FDRE Water Policy, supra note 99.

${ }^{122}$ S. S. G. (1935) 'Waters: Riparian v. Non-Riparian: Reasonable Use', California Law Review, Vol. 23, No. 5, pp. 540-542.

${ }^{123}$ FDRE, Rural Land Administration proclamation 456/2005, Art 5(1) (a), and Art 5(2)

${ }^{124}$ Mastewal Y., supra note 112, p, 139. The sampled study sites are 'Mesanu' and 'Chelekot' in Tigray, 'Kuhar Michael' and 'Angot' in Amhara, and 'Suka' in SNNP regional states, Ethiopia

125 François Piguet, supra note 108, p, 8.

${ }^{126}$ See, for example, FDRE, Awash Basin Authority (2015/16), 'Water scarcity gets serious', An assessment made on sustainable allocation of water for 2015/16. Available at <http://www.awba.gov.et/water-scarcity-gets-serious/> last visited on March 25/2016.

${ }^{127}$ Starting from the public trust doctrines and other reasoning, it may be justified the list has impliedly shown the order of priority. 


\subsubsection{Interplay between Ethiopia's Water Policy 'goals' and the standard tests}

The policy has a general goal of ascertaining "efficient, equitable and optimum utilization of water resources of Ethiopia for significant socioeconomic development on sustainable basis". ${ }^{128}$ Due to lack of clear and sufficient standard tests in the policy, the general goals of the policy may be examined against the potential standards to test whether it implicitly embodies any of them with a view to set order of priorities. Two core elements of the policy's general goal, i.e. "efficiency" and "equitable and optimum utilization of water resources" require careful interpretation.

\section{a) Efficiency}

The goal of bringing 'efficiency' may be related with the beneficial use of water to bring high productivity with less volume of water. As stated above, the beneficial use test avoids wastage of water. ${ }^{129}$ Using less volume of water is one of the manifestations of the beneficial use standard test. ${ }^{130}$ While some consider this principle as variable, others define it as water used only for agricultural, industrial and household purposes. ${ }^{131}$ The word 'efficiently' in Ethiopia's Water Policy implicitly endorses the beneficial use of water since efficient utilization of water avoids wastage.

The policy's goal of bringing efficiency may be related with the narrower and broader characterization of beneficial use. The 'beneficial use' test is, for example, interpreted in different ways in the water laws of US. ${ }^{132}$ Some of the states interpret it very strictly by stating very specific and limited uses. The uses are such as agricultural, industrial, domestic uses, power uses, municipal uses and other public interest based uses. ${ }^{133}$ Some other states have a broader

${ }^{128}$ See also Zemede Abebe et al., supra note 1, p.1. The consortium has magnified these as pillar goals for "....promoting integrated water resources management."

129 Marika Van Der Walt and Gerrit Piennar, supra note 90, p. 426. They claim the beneficial use was applied to bring equitable utilization starting from the Roman times.

${ }^{130}$ The FDRE water policy, supra note 99, p. 10. For example, the overall purpose of the policy is to "promote all national efforts towards the efficient, ... .utilization of the available Water Resources of Ethiopia for significant socioeconomic development on sustainable basis."

131 Samuel C. Wiel, supra note 16, p. 465. "It is evident that the reasonable degree of perfection of each of these requirements will vary with the locality and with different changing conditions in each locality, so that the beneficial use of water is a variable."

${ }^{132}$ Id., p. 461. Beneficial use was first considered through the amount of water requested through permit, or the capacity of the appropriator's to use targeted water resource but argues water use is a variable.

${ }^{133}$ See, for example, Irwin S. Moise (Justice, Supreme Court of New Mexico) 'Concept of beneficial Use in the water law of New Mexico', Santa Fe, New Mexico, p. 112.

Available at $<$ http://www.wrri.nmsu.edu/publish/watcon/proc4/Moise.pdf $>$ last visited 
spectrum which includes other uses: such as urban and environmental uses. ${ }^{134}$ The practical need to restrict or broaden the scope of interpretation of the beneficial use test thus depends on the availability of water resources. ${ }^{135}$ Where water resources that are vulnerable are abundant, a broad interpretation of beneficial encourages water utilization free of conflicts and water use problems. ${ }^{136}$ On the other hand, the beneficial use test is narrowly interpreted where there is scarce or unevenly distributed water, as a result of which the standard test is limited to specific types of uses in order to address the risks of conflict, water grabbing and wastage of water. ${ }^{137}$

At present, there is 'uneven water distribution' in Ethiopia. ${ }^{138}$ This leads to relatively varied interpretations of 'beneficial use' in various regional states depending on the degrees of water scarcity, and it will be construed narrowly in the regions that are prone to water scarcity. The policy is thus expected to relate the goal of efficiency with the uneven distribution of water resources across the country. In effect, there may be the need to contextualize the specific types of uses to specific geographic and natural resource contents found across the country. ${ }^{139}$

on Jan 10, 2015. He stated a public interest based definition has been suggested in the National conference of Commissioners on uniform state law for Model Water Use Act. These public interest uses do not cause any change in the substantial volume of water resources such as navigational, fishing and wild life, and recreational uses.

${ }^{134}$ See, for example, Porter-Cologne Water Quality Control Act (California Water Code, Division 7, Chapter 2 section13050) and California Water Code section 13050(f), available at $<\mathrm{http} / / \mathrm{www}$.leginfo.ca.gov/cgi-bin/displaycode?section=wat\&group=13001$14000 \&$ file $=13050-13051>$ last visited Jan 8, 2015. It has defined "Beneficial uses of the waters of the state that may be protected against quality degradation include, but are not necessarily limited to, domestic, municipal, agricultural and industrial supply; power generation; recreation; aesthetic enjoyment; navigation; and preservation and enhancement of fish, wildlife, and other aquatic resources or preserves."

${ }^{135}$ Mayo H. Stiegler, (2004) 'Use of Available Water Is Key to Water Rights Forfeiture', Journal (American Water Works Association), Vol. 96, No. 1, p. 27. The supreme court of Idaho ruled that junior appropriator can defeat the forfeiture of the senior if he /she have used the available water for 'beneficial purpose' after the statutory period of nonuse has elapsed. It was open to interpretation.

${ }^{136}$ See, for example, Marika Van Der Walt and Gerrit Piennar, supra note 90, p, 423.

${ }^{137}$ Id., p. 418. Citing Principle 3 of the White Paper on a National Water Policy (1997) 60 $<$ www.dwafgov.za> (06-01- 2012)). "There shall be a right to water or an authorisation to use water only for environmental and basic human needs."

138 FDRE Water Policy, p. 1. Introduction part of the policy.

${ }^{139}$ See, for example, Samuel C. Wiel, supra note 16, p. 465. He finally noticed from the US case laws that beneficial use is a variable. 


\section{b) Equitable and optimum utilization of water resources}

The 'equitable and optimum utilization' goal of the policy may represent the reasonable use test. ${ }^{10}$ Accordingly, facilitating the reasonable use of water resources envisages prioritizing domestic use or as some call it 'natural use' or 'ordinary use' of water. ${ }^{141}$ The reasonable use is broadly interpreted in Colorado v. New Mexico 467 U.S. 310 (1984). The reasonable use standard is conducive to the human rights to water. Domestic use representing the reasonable use also comprises the utilization of water resources for drinking, cooking, washing etc. ${ }^{142}$ It can also include wider aspects of 'reasonable' use. ${ }^{143}$

The earlier doctrine is comprised of two elements: the natural flow of the water resource and the potential right of the appropriators possessing or owning land contiguous to the water resource. ${ }^{144}$ The word 'optimum' may qualify the reasonable use while the intersection between reasonable use and equitable utilization, and the effective interpretation of both may have an implication on ordering of priorities. Although the policy may seem to have impliedly embodied the standard test, it may become superfluous since there are no clear and adequate priorities other than implied interpretations.

The 'equitable utilization' test also stands for fair allocation and equitably shared utilization of water resources. ${ }^{145}$ This may be broadened to bring equity or justice among the users from the same water resource. ${ }^{146}$ However, this is applicable in 'out of priority' water use right system and the same goes in the policy, since the policy's position is unclear in setting out the order of priorities thereby failing to adequately protect the interest of some vulnerable individuals or groups. One of the indicators of equity is "... whether laws exist that recognize the need for disadvantaged groups to be treated differently". ${ }^{147}$ It may also be broadened to share burdens equally, as in the case of riparian water users who may bear equal burden where there is seasonal shortage of water

\footnotetext{
${ }^{140}$ See, for example, Anthony Scott and Georgina Coustalin, supra note 5, p, 847. In English case law, courts of Equity were established to receive personal petition justifying that equity was the prevailing of all.

${ }^{141}$ See, Id, p. 867.

${ }^{142}$ FDRE Water Resources' Management Proclamation, 197/2000. Art 2(6).

${ }^{143}$ Vicente S. Pedrero, (1966) 'A New Approach to the Problem of Domestic Pollution', Ekistics, Vol. 22, No. 132 pp. 337-339. The author defines domestic use as ".....Domestic use includes showers, wash basins, kitchens, etc"

${ }^{144}$ Anthony Scott and Georgina Coustalin, supra note 5, p. 831.

145 See Art 5 and Art 21(2) of the UN convention stating "equitable and reasonable utilization" and "beneficial purpose" respectively.

${ }^{146}$ Jeanne Luh et al. (2013) 'Equity in water and sanitation: Developing an index to measure progressive realization of the human right', International Journal of Hygiene and Environmental Health, 216, pp. 662-671

${ }^{147}$ Id., p. 664.
} 
resources. ${ }^{148}$ The doctrine obliges users not to affect the interest of other riparians during water use from the natural flow. ${ }^{149}$ Impliedly, the concept of equitable utilization reflects the spirits of the reasonable use among the nonexpressly and non-exclusively ordered priorities.

The principle of 'equitable and reasonable utilization' is the standard test applied in international shared watercourses or trans-boundary waters among riparian countries. ${ }^{150}$ There are instruments that "foster meaningful and mutually fair regional cooperation and agreements on the joint and efficient use of trans boundary waters with riparian countries based on 'equitable and reasonable' use principles". ${ }^{151}$ The application of both standards in international water law shows their mutual relations. Even though, Ethiopia's Water Policy seems to manifest the concept of reasonable use, the role of reasonable use in prioritizing water use rights is blurred since there are no clear and express directions of priorities under the policy.

Through the strict interpretation of equitable utilization, it is reasonable to enforce the right of non-riparian potential users. ${ }^{152}$ Currently, the reasonable use test is credited for the role it plays in assuring the interest of other non-riparian landholders with the view to mainstream the real spirit of equity. ${ }^{153}$ This was the common manifestation of the Ethiopian 1960 Civil Code in giving the right of other non-riparian users to use water from the watercourse by installing water pipes. ${ }^{154}$ The Rural Land Administration Proclamation also manifests the equitable utilization of water and it allows other adjacent landholders to use from the watercourse through irrigation canals and other infrastructures. ${ }^{155}$ Apart from this, the law states that "... equitable water use system shall be

${ }^{148}$ Anthony Scott and Georgina Coustalin, supra note 5, p. 830.

${ }^{149}$ Id, p. 862. See also, Art 5(1) of the UN Convention states, an international water course shall be used by water course states "... with a view to attaining optimal and sustainable utilization thereof and benefits therefrom ..."

${ }^{150}$ Convention on the Law of Non-Navigational Uses of International Watercourses, Art 5 G.A. Res. 51/229 of 21 May 1997

${ }^{151}$ Salman M.A. Salman, supra note 7.

${ }^{152}$ See for example, Id, p. 870. It has featured 'prior-user' among others as "Legal access could be granted in the form of contracts or easements, and non-riparian thereby permitted to take stream water inland across riparian lands and return it by artificial channels."

${ }^{153}$ Jeanne Luh et al, supra note 146, p, 663. The trend has shifted to substantive equality. "While substantive equality is sometimes used interchangeably with the term 'equity' in the field of water, sanitation, and hygiene, of these two terms, substantive equality is the only human rights concept reflected in human rights treaties."

${ }^{154}$ See, for example, Civil Code, 1960, Arts. 1220 and 1249.

${ }^{155}$ FDRE Rural Land Administration Proclamation 456/2005, Art 10(2). 
established between upper and lower watershed communities". ${ }^{156}$ In effect, the policy and the related laws have directly or indirectly embodied the standard tests but there are no clearly and sufficiently embodied orders of priorities.

\subsection{The Ethiopian water resource management laws}

Ethiopian water law is deep rooted in the old land and property laws dealing with the regulation, control, administration and dispute adjudications pertinent to water issues. ${ }^{157}$ Water issues are directly or indirectly linked to land issues. ${ }^{158}$ The regulation and administration of rural or urban, directly or indirectly impacts the regulation and administration of water issues. The laws and policies of land issues also encompass the laws and policies of water issues. ${ }^{159}$ Both laws are thus two sides of the same coin.

The current Ethiopian water laws are not detailed and codified; and have developed from earlier laws and policies. ${ }^{160}$ The current governing law with regard to water issues is the FDRE Water Resources Management Proclamation. ${ }^{161}$ Its features and their implications are discussed below in order to search for the standard tests in prioritizing water use rights. The clarity, specificity, sufficiency and comprehensiveness of the laws in embodying standardized priorities are examined.

\subsubsection{Features of the law and implications on searching for the standard tests}

The law has a broader scope and it regulates the management, protection and utilization of water resources in Ethiopia. ${ }^{162}$ Whereas the preceding repealed Water Resources Utilization Proclamation only dealt with regulating the utilization of water resources, the current proclamation further regulates the management aspect of water resource. ${ }^{163}$ The management of water envisages setting out order of priorities. Its major purpose is to ensure that "the water resources of the country are protected and utilized for the highest social and economic benefits of the people of Ethiopia." 164 This is in conformity with the

\footnotetext{
${ }^{156}$ Id., Art 13(2).

${ }^{157}$ Civil Code, 1960, Title VII. Individual Ownership, Chapter 1 Acquisition. Transfer, extinction and proof of ownership starting from Art 1151 and the following.

${ }^{158}$ S. Hodgson, (2004) Land and water -the rights interface, FAO Legislative Study 84, pp. iii.

159 Ibid.

${ }^{160}$ The current proclamation is not detailed and codified even the 1960 civil code was codified and detailed one.

${ }^{161}$ FDRE Water Resources Management Proclamation 197/2000.

${ }^{162}$ Id., see, the preamble of the Proclamation.

${ }^{163}$ Id., Art 32(1) stating, "The Water Resources Utilization Proclamation No. 92/1994 is hereby repealed."

${ }^{164}$ Id., see, paragraph 1 of the preamble and the third line sentence of Art 3.
} 
current understanding of sustainable development where the environment or the different natural resources are taken as the base, and the economy as the tool to bring about the ultimate target, i.e. social benefits. ${ }^{165}$ The Proclamation implies the purpose of balancing these three conflicting interests accompanied with conflicting priorities of developments.

The Proclamation also states the environmental problems associated with the harmful effects on water. ${ }^{166}$ It states the need to supervise that the water resources are 'duly conserved' and 'ensure the harmful effects of water are prevented'. ${ }^{167}$ This reflects the need for carrying out proper and 'due management' of water resources in general. ${ }^{168}$ The intention of the law to conserve and manage water resources manifests the reasonable use standard. ${ }^{169}$

The other pillar of the Proclamation relates to 'public ownership' of water resources which departs from the 1960 Civil Code that, in principle, envisages communal ownership and use. ${ }^{170}$ As stated above, public ownership of water is in tandem with the public trust doctrine. The wording of this provision is similar with the FDRE's Constitution provision dealing with the ownership of land. ${ }^{171}$ Both provisions reinforce each other by showing the inseparability or indivisibility of both resources. The administration and regulation of land and water resources also comes under interlinked organs. ${ }^{172}$ The concept of public ownership indeed requires the law to set priorities accompanied by pertinent standard tests with the view to balance the apportionment of resources for public and private uses.

The Proclamation puts some helpful fundamental principles for its implementation. It states the 'integrated master plan studies and water resources legislative framework' should be used as a tool or a 'point of reference' for testing whether any water resource is utilized 'to the highest social and economic benefit of the people of Ethiopia'. ${ }^{173}$ It also requires that the social and economic programmes, investment plans and any person's water resource development activity is expected to be 'based on the country's Water Resources

${ }^{165}$ See, for example, Andrea Ross, supra note 26, p, 34. He stated sustainable development is construed because it legitimizes 'business-as-usual' patterns of economic growth.

${ }^{166}$ FDRE Water Resources Management Proclamation 197/2000, Art 3.

${ }^{167}$ Ibid.

${ }^{168} \mathrm{Id}$., paragraph 1 of the preamble.

${ }^{169}$ Since they are applied as tests

${ }^{170}$ See Art 5 of Proclamation 197/2005 and Art 1228 of Civil Code (1960).

${ }^{171}$ Id., see the cumulative reading of Art 5, stating "...All water resources of the country are the common property of the Ethiopian people 'and the state." And Art 43(3) of the FDRE Constitution.

172 Ibid.

${ }^{173}$ FDRE Water Resources Management Proclamation 197/2000.Art 6(1). 
Policy, the relevant Basin Master Plan Studies and Water Resources Laws' ${ }^{174}$ This is comparable with the Spanish Water Law, which requires setting a plan and its pursuance based on order of priorities. The supervising body and its delegates are also given the mandate to ensure and administer the management of water resources. ${ }^{175}$

The other major principle and feature of managing water resources of Ethiopia is the requirement of permit ${ }^{176}$ for water uses other than domestic uses and other uses that are provided as exceptional uses under the law. ${ }^{177}$ As Pedrero notes, "... the basic water need of a community is for domestic, commercial and public uses". ${ }^{178}$ The requirement of permit helps the state to keep and preserve water based on public interest toward effective and efficient use. ${ }^{179}$

The permit system may be an opportunity or a challenge because it may have direct and/or indirect impacts on weakening or strengthening the priority of uses where there are unranked water users with potential conflicting interests. The law requires permit for some water related works or investments from the concerned bodies $^{180}$ that may properly use, or on the contrary misuse this public trust. The concerned bodies are thus expected to test the reasonable, beneficial, and/or beyond other proposed uses of water prior to the issuance of permits. One of the challenges, however, lies in the fact that two organs, i.e., the Federal Investment Commission and Ministry of Water, Irrigation and Energy and its delegates ${ }^{181}$ may see a project proposal's feasibility through different standard tests. ${ }^{182}$ While, this can secure prior established rights by prior-appropriators, ${ }^{183}$

${ }^{174}$ Id., Art 6(2)

${ }^{175}$ Id., Art 6(3)

${ }^{176}$ Id., see, the cumulative reading of Art. 6(4), Art 11 and Art 12of the proclamation.

${ }^{177}$ Id See Art 7(1) about domestic use and Art 12(1) stating : "(a) dig' water wells by hand or use water from Hand-dug wells; (b) .use "water for traditional irrigation, artisanal, mining and for traditional animal rearing, as well as for water mills."

178 Vicente S. Pedrero, supra note 143, p. 338. The three basic users are compared and contrasted. “... Domestic use includes showers, wash basins, kitchens, etc.; commercial use covers a much wider range; and public use includes water for public parks and gardens, street cleaning, irrigation, etc."

179 See, for example, Alexandra B. Klass and Ling-Yee Huang, supra note 24, p. 4. For example, it allows for citizens " ... litigating the public trust doctrine has also resulted in government accountability and citizen empowerment by permitting citizen suits against the state for failure to uphold trust."

${ }^{180}$ Id., Art 11

${ }^{181}$ Id., Art 2(7) defines the supervising body is the Ministry allocating water resources and other its delegates.

${ }^{182}$ Since the Ministry of Water and Energy will check first its feasibility and send it to the Concerned Investment organs. 
it may bring lengthy bureaucratic procedures and water may be wasted and left unused for beneficial purposes.

On the other hand, this can discourage wastage since pre-allocation or a plan to a specific use does not hinder other potential users to make beneficial use of the water resource. ${ }^{184}$ The law seems to favour the beneficial use of water since first or prior appropriators of water are allowed to continuously use it. ${ }^{185}$ The domestic use and beneficial use may clash since there is no a clear border. Yet, the law gives absolute protection to domestic use, and any other subsequent use is expected to be in conformity with domestic use. ${ }^{186}$ Unlike the policy, the law embodies express priority rule in favour of domestic use. However, the demarcation of priorities between domestic use and prior established rights through prior appropriation is not clearly standardized. According to Mehta, L et $a l$, the FDRE Water Resources Management Proclamation is a model in protecting local users' 'legitimate interests'. On the contrary, Ethiopia is mentioned as a country where 'land grab' occurs in the course of large scale land acquisition by foreign agricultural investments. The law does not set the 'preference among uses' in clear, comprehensive and sufficient way.

The law does not also state any standard test to regulate the relation among domestic users. The reasonable use standard may be applied as a minimum standard to regulate the priority of specific uses even among the cluster of domestic users. ${ }^{187}$ As it is commonly stated, the minimum priority of water use right is given to domestic uses. ${ }^{188}$ This is associated with the reasonable use test to balance the interest of upper and lower riparians. The interconnections of the riparian land holders bring correlative rights and duties. ${ }^{189}$ The domestic use may be related with reasonable use as a right to get priority and a duty not to inflict harm to other potential users. There is no clear and express provision of

${ }^{183}$ See FDRE Water Resource Management Proclamation 197/2000, Art 7(2), prior appropriators have the right to use the water even it is planned or pre-allocated for other use.

${ }^{184}$ Ibid.

${ }^{185}$ Id., see for example, Art 2(1) defines water works a "....putting for the purpose of beneficial use." Art 10(1) also put the necessity of preparing water resources inventory for beneficial uses. Art 16(1) a permit holder may apply to make an increase or decrease of the quantity of water permitted "...to use water for other beneficial use."

${ }^{186}$ Read both Art 7(1) and 7(2) and see how they may impact one another.

${ }^{187}$ See, Art 2(4), Even it has defined what constitutes domestic use; it is defined broadly and left as illustrative one.

${ }^{188}$ See, Anthony Scott and Georgina Coustalin, supra note 5, p, 830. It is stated there is a 'spill over' or a dependence of one on the other.

189 Anthony Scott and Georgina Coustalin, supra note 5, p, 832. "In a system of common law rights, strengthening rights over the water flowing by a property has meant greater interdependence among riparian and thus less exclusivity." 
the reasonable use under the law while it may be inferred from the riparian doctrine.

Hence, it is important to note whether the priority given to domestic use by the law considers the riparian doctrine and inquire into its practical challenges during implementation. Most rural landholders in Ethiopia live in riparian settings and the practicability of capturing water resource from its natural flow without affecting the interest of the majority is unlikely and rare. ${ }^{190}$

This challenge can be attributed to uneven spatial distribution, water inefficiency, absence of conservation works and gaps in sustained investment in the water sector to satisfy the need of water to all the riparian and non-riparian water users. ${ }^{191}$ Chronic droughts caused by El'-Niño and other factors across the country $^{192}$ indeed aggravate the challenges in this regard. The large majority awaits the two or three months rainfalls ${ }^{193}$ and any available water will also be used for traditional irrigation. There are tendencies of allocating scarce water resources for communal uses disregarding issues of priority. ${ }^{194}$ This opens a door to the tragedy of the commons and causes water use problems. This mainly results from the insufficiency of the order of priorities with clear standard tests.

The other feature of the law regarding the implied incorporation of the reasonable use is its exemption of few water uses from permit. These exemptions include 'traditional irrigation, artisanal mining, and traditional animal rearing as well as ... water mills'. ${ }^{195}$ The exemptions broaden the place given for reasonable use in the law. The rationale of primacy for domestic use and reasonable use also relate to justification of survival ${ }^{196}$ because the right to

${ }^{190}$ Id., p. 850. It has shown a development in which it gave to "the non-riparian; the enforceable usufructuary right to the water's flow."

${ }^{191}$ See FDRE water policy, that there is uneven distribution and insufficient water distribution across the country. The policy states them as challenges.

192 See, for example, FDRE, Awash Basin Authority (2015/16), supra note 130, "The Awash River water has been currently facing water shortages, due to growing demands for irrigation water and potentially due to effect of El Nino which is by far reducing the availability of water in dam reservoirs, lakes and swamps."

${ }^{193}$ See, for example, Gulilat Birhane, 'Present and Future Water Resources Development in Ethiopia Related to Research and Capacity Building', A proceeding for workshop with stakeholders, Planning and Projects Department, Ministry of Water Resources, Addis Ababa, Ethiopia. Available at $<$ http://publications.iwmi.org/pdf/H032445.pdf $>$ last visited on Dec, $5 / 2015$

${ }^{194}$ See Alexandra B. Klass and Ling-Yee Huang, supra note 24, p. 1.

${ }^{195}$ See FDRE Water Resource Management Proclamation 197/2000, Art 12.

${ }^{196}$ See Anthony Scott and Georgina Coustalin, supra note 5, p, 867. “.... that all might drink it, or apply it, to the necessary purposes of supporting life; and that no one had any property in the water itself, except in that particular portion....". 
life is beyond any right. ${ }^{197}$ However, there are debates on how basic human needs may be characterized: i.e. whether the domestic use includes small scale agriculture or not. ${ }^{198}$ The law does not clearly and comprehensively address these issues.

The law also manifests the reasonable use of underground water which is dug by hand or obtained from hand dug wells. ${ }^{199}$ There are different positions (either restrictive or permissive) of laws in governing the uses of underground water resources. $^{200}$ For example, the Ethiopian water law bans the use of technological instruments for digging activities. The muscles or number of diggers thus determine the extent of extracting underground water. This indirectly shows that the law partially allows private use of underground water resources. This seems inconsistent with the 1960 Civil Code which designates underground water as a public domain. ${ }^{201}$ The FDRE Water Resource Management Proclamation expressly repeals any law, regulation, directive, guideline or practice that conflicts with the proclamation ${ }^{202}$ thereby sidelining the Civil Code provisions on underground water that are inconsistent with the Proclamation. In this regard, the law's position may be related with reasonable use. However, unless the use of underground water resources is carefully prioritized by clear standards, it can cause pollution and depletion.

The place given to beneficial use under the Proclamation can, inter alia, be observed from the statement which requires the supervising body to issue a directive if there is any 'inappropriate use' and 'wastage of water' with regard to the exempted uses. ${ }^{203}$ However, it does not state clear restrictions to uses other than the uses exempted from permit. As discussed above, the beneficial use of water developed based on the justification of avoiding wastage. $^{204}$ However, the limitation may be a challenge to individuals using water for domestic use, since there is an open ended or illustrative definition of domestic

197 Antonio Embid Irujo, (2007) 'The Right to Water', International Journal of Water Resources Development, 23:2, pp, 267-283. Citing Art 12 paragraph 1 of International Declaration of Human Rights (1948)

${ }^{198}$ Tom Le Quesne and Constantin Von Der Heyden, (2007) 'Allocating scarce water, A primer on water allocation, water rights and water markets', WWF water security series 1, p. 4.

199 See FDRE Water Resource Management Proclamation 197/2000, Art 12(1).

200 See for example, Donna M. Cosgrove, (2008) The Role of Uncertainty in the Use of Ground Water Models for Administration of Water Rights, Journal of Contemporary Water Research \& Education (Universities Council on Water Resources) Moscow, Issue 140, pp. 30-36.

${ }^{201}$ See Art 1255 of Civil Code of the Empire of Ethiopia, 1960.

202 See FDRE Water Resources Management Proclamation, Art 32(2)

${ }^{203}$ See Id., Art 12(2).

${ }^{204}$ See Samuel C. Wiel, supra note 16. 
use, and for the additional uses exempted from permit. ${ }^{205}$ It may restrict and impugn the definition of domestic use and the potential reasonable priority gained by the law.

Although, Ethiopia's law on water use bears the features of both standard tests, it lacks clarity, comprehensiveness and sufficiency. The enforcement of the standard tests, with their holistic legal, normative and theoretical frameworks, from the outset of the law is not thus feasible. It puts priority right to use water for domestic use but it does not embody the reasonable use while it has predominantly used the term beneficial use in most of its provisions. ${ }^{206}$ It does not also define the beneficial uses since it may have broader or narrower application. Therefore, there should be clear, sufficient and comprehensive rules in qualifying and defining both standards with the need to set order of priorities. The following section briefly examines the objectives of the law in searching for the standard test.

\subsubsection{Water uses for 'highest social and economic benefits': Meaning and implications}

The law entrusts the supervising body to administer and regulate the water resources of the country in order to attain the highest social and economic benefits. The meaning and the indications of water uses that can attain the highest social and economic benefits are not clearly stated. ${ }^{207}$ However, the law puts an important requirement that the social and economic programmes, investment plans and any person's water resource development activity are expected to be 'based on the country's Water Resources Policy, the relevant Basin Master Plan Studies and Water Resources Laws'. ${ }^{208}$

The difference between social and economic benefits can be observed from the international human rights instruments, the FDRE Constitution and other national laws and policies. For instance, Under the FAO Legislative Study, Stephen Hodgson states that "... the right to water is a putative human right which is claimed to exist either as a right in itself or as an ancillary aspect of the "right to food" created by article 11 of the International Covenant on Economic,

${ }^{205}$ See FDRE Water Resources Management Proclamation 197/2000, Art 2(2). It ends with the phrase "... and other uses."

${ }^{206}$ See FDRE Water Resources Management Proclamation 197/2000,See for example, Art 2(1) defines water works a "....putting for the purpose of beneficial use." Art 10(1) also put the necessity of preparing water resources inventory for beneficial uses. Art 16(1) a permit holder may apply to make an increase or decrease of the quantity of water permitted "...to use water for other beneficial use."

${ }^{207}$ See FDRE Water Resources Management Proclamation 197/2000. Paragraph 1 of the preamble, Art 2 (the definition part) and Art 6 do not define 'highest social and economic benefits'.

${ }^{208}$ See FDRE Water Resources Management Proclamation 197/2000, Art 6(1). 
Social and Cultural Rights". ${ }^{209}$ The FDRE Constitution embodies social objectives including access to public health and education, clean water, housing, food and social security. ${ }^{210}$ The FDRE water policy document also ensures water allocation for the "... highest priority to water supply and sanitation". ${ }^{211}$

The FDRE water resources management laws give priority of water uses for domestic use, traditional irrigation, and other similar uses. In the absence of clear definitions or stipulations, the social benefit can include the use of water in smallholder subsistence farming, water supply, sanitation purposes, domestic uses, traditional irrigation and other similar uses. Such water uses manifest reasonable use and may be set as priorities.

Economic benefits can be distinguished from the social benefits where the benefits are accrued at an individual level for primarily personal economic gain or purpose. The meaning of economic benefit can be narrowly construed where the decision is made at an individual level for non-social purposes to pursue personal economic returns or ends. The economic benefit of water, for example, includes the transfer of water or the right attached to water or the use of water as a commodity for further economic productive activities at an individual level. ${ }^{212}$

However, the economic benefit of water to the society at large may be cumulatively considered as social benefit even though in the strict sense the accrued benefit is both economic and social benefit. Economic intervention may thus be made towards social ends and vice versa. ${ }^{213}$ The FDRE water policy reflects the mutually non-exclusive understanding of both benefits. ${ }^{214}$

The government has the "...duty to hold, on behalf of the People, land and other natural resources and to deploy them for their common benefit and development". ${ }^{215}$ The Federal government has the power to 'determine and administer' the utilization of water resources and rivers that link two or more states. ${ }^{216}$ The power of deciding on water uses and their corresponding expected benefits (either for social, economic and the combination of both) is given to the

\footnotetext{
${ }^{209}$ Stephen Hodgson, supra note 3, p, 8 .

${ }^{210}$ See FDRE Constitution, Art 90(1).

${ }^{211}$ See FDRE Water Policy, supra note 99, p.5.

${ }^{212}$ Stephen Hodgson, supra note 3, p. 86.

${ }^{213}$ See FDRE Constitution, Art 89(2), equal opportunity, Art 89(4) Special assistance, Art 89(6) participation of the people, government's duty to protect and promote the health, welfare, living standard states all these as economic objectives of the country.

${ }^{214}$ See FDRE Water Policy, p, 5. The purpose is to “....[e]nsure that water allocation gives highest priority to water supply and sanitation while apportioning the rest for uses and users that result in highest socio-economic benefits."

${ }^{215}$ See, FDRE Constitution, Art 89(5).

${ }^{216}$ See FDRE Constitution, Art 51(1).
} 
Federal government provided that the water resource or river links two or more regional states.

On the other hand, the FDRE Constitution empowers regional states to administer land and other natural resources in accordance with the Federal laws. ${ }^{217}$ Accordingly, the regional states have the power to determine the types and nature of benefits as long as they are consistent with the Federal laws and the social and economic objectives stated under the FDRE Constitution and the FDRE Water policy. Irrespective of the level of the supervising body and its delegates, these organs are required to ensure and administer the management of water resources to attain the 'highest social and economic benefits'. ${ }^{218}$

Typical examples of economic benefits can be discerned from the activities and achievements of various economic activities in river basins. The annual report on Awash River Basin states the socio-economic resources, activities and benefits of water. ${ }^{219}$ The synthesis report cites the FDRE water policy as an authority and cross-refers the phrase 'socio-economic' throughout the whole discussion of the report. ${ }^{220}$ However, the economic use of Awash River Basin is described as the use of water for power generation, mining, agriculture and tourism. ${ }^{221}$

The report notes the need for monitoring and documentation system of the river basin to bring efficient and beneficial utilization of the finite water resource. ${ }^{222}$ Unlike the gaps in the law with regard to irrigation, the synthesis report calls for cautious plan by accommodating the competing uses, the environment and an overall consideration to the 'economic viability of irrigation in the basin'. ${ }^{223}$ Therefore, water from the river basin is used for economic benefits while social benefits are also obtained. Yet, water is -under such contexts- utilized more for economic benefits than social benefits. Thorough examination of the synthesis report shows that the beneficial use or the economic benefit of water is the standard test applied to use water from the Awash River Basin.

In the context of foreign direct investment, Bossio states that foreign direct investors benefit better in water use as compared to the small farmers of the

\footnotetext{
${ }^{217}$ See FDRE Constitution, Art 52(2)(d)

${ }^{218}$ See FDRE Water Resources Management Proclamation 197/2000, Art 6(2).

${ }^{219}$ FAO (2013), Synthesis Report on Awash River Basin Water Audit, GCP/INT/072/ITA, Addis Ababa, Ethiopia Available at

$<$ http://www.fao.org/nr/water/docs/awash/AwashSynthesisReport.pdf $>$. Accessed: July 15,2016

${ }^{220}$ Id., p, 2.

${ }^{221}$ Id., p, 6 .

${ }^{222}$ Id., p, 30,

${ }^{223}$ Id., p, 31.
} 
local population due to 'better bargaining power of the investors and support of the government'. ${ }^{224}$ The government seems to have been attracted by the economic benefit from tax and other revenues that can potentially be levied and collected from the investors. The benefit is accrued at an individual level by the investors. Andrea also notes how agricultural foreign direct investment affects water rights of communities. ${ }^{225}$ It is argued that the economic benefit weighs off the social benefit and the social benefit may be indirectly provided by the government through provision of infrastructures and social welfare services. According to this line of argument, the attainment of the highest social and economic benefit as an objective of the law may be aligned with the beneficial use of water aiming at tangible economic returns. In light of the controversy that can relate to the proper balance in this regard, policy options should be examined on how to incorporate clear, sufficient and comprehensive standard tests towards prioritizing water uses.

\section{Options in Applying 'Reasonable Use' and 'Beneficial Use' Standards}

\subsection{Allocating water in order of priority}

States are under obligation to allocate water resources to private uses, for communal uses and public uses after considering the natural, social, economic and environmental circumstances. ${ }^{226}$ The Ethiopian water law states that all water resources are given to the ownership of state. Basically, water allocation and water regulation depends on the abundance of water. If water is scarce, the regulation of its use will be more restricting and vice versa. ${ }^{227}$ 'Water crisis' exists in many countries due to "inefficient use, degradation of the available water by pollution and the unsustainable use of groundwater resources." 228 The standardized options are needed to consider these issues during water allocation.

Water allocation is described as a process whereby any available water resource is distributed to "legitimate claimants and the resulting water rights are

${ }^{224}$ Bossio, D. et al. (2012) 'Water Implications of Foreign Direct Investment in Ethiopia's Agricultural Sector'. Water Alternatives 5(2): 223-242.

225 Andrea Bues, (2011) 'Agricultural Foreign Direct Investment and Water Rights: An Institutional Analysis from Ethiopia', Paper presented at the International Conference on Global Land Grabbing, Organised by the Land Deals Politics Initiative (LDPI) in collaboration with the Journal of Peasant Studies and hosted by the Future Agricultures Consortium at the Institute of Development Studies, University of Sussex

${ }^{226}$ A. N. Yiannopoulos, (1961) 'Common, Public, and Private Things in Louisiana: Civilian Tradition and Modern Practice', Louisiana Law Review, Volume 21 | Number 4.

${ }^{227}$ See Quesne \& Heyden. supra note198.

${ }^{228}$ Sharad K. Jain \& Vijay P. Singh, (2010) 'Water crisis', Journal of Comparative Social Welfare, 26:2-3, pp. 215-237. 
granted, transferred, reviewed, and adapted". ${ }^{229}$ The phrases water rights and water allocation are used in different ways in differing contexts. ${ }^{230}$ In some instances, 'water allocation' can refer to a particular entitlement ${ }^{231}$ or right, rather than the process. It is also to be noted that 'human right to water' evokes different concepts. ${ }^{232}$ It is thus the legal regime of a country that must articulate the right with due clarity and enforceability. However, Ethiopian law does not define water use right or water allocation other than embodying an illustrative list on the types of water use.

The order of priority on the use of water can generally consider the degree of availability, legal norms, right approaches and impact on water. Having considered these factors, priority is first given to "[b]asic human needs and key social purposes, ecosystem integrity, and economic development". ${ }^{233}$ However, this order of priorities is comprised of very general terms and its elements can entail different interpretations. Uses of water for 'economic development' by individuals, groups and communities thus require their own characterization and standard tests with a view to setting orders of priorities.

The availability and reliability of a given water resource should be considered on the basis of the demands of multiple uses within a specific period of time. ${ }^{234}$ As stated above, the US Supreme Court decision on Colorado v. New Mexico illustrates the need for setting order of priorities in the allocation of water. Based on Hydrologic modelling in USA, water was allocated 'to each right in priority order' for each month of the hydrologic period determined after examining the availability of water and the potential number of uses or users. ${ }^{235}$ Therefore, the decision to order priority highly depends on the availability of water resource and its reliability to fulfil the needs of the uses. Thus, shifting the allocation of water from one order to another order of priority is impossible if the available water does not cover the needs of all users.

${ }^{229}$ See Quesne \& Heyden, supra note198, p. 10.

${ }^{230}$ Id., For example, the concept of 'water rights' can sometimes be used to refer to the entire water allocation process.

${ }^{231}$ See MarikaVander and Gerrit Pienar, supra note 90, p. 418. Citing, Republic of South Africa National Water Act 36 of 1998 s 1. It defines 'entitlement'..."to mean a right to use water in terms of any provision of the act or in terms of an instrument issued under the act." "It emphasises the fact that an entitlement existing in terms of the act remains a right to use water."

${ }^{232}$ See Quesne \& Heyden. supra note 198, p, 10. Water is not a commodity to be allocated to create rights rather accessed automatically without allocation.

${ }^{233}$ Id., p. 4.

${ }^{234}$ Ralph, A Wurbs et al, (2001) 'Assessing Water Availability Under A Water Rights Priority System', Journal of Water Resources Management and Planning, pp, 235 -243.

235 Id., p, 237. 
In light of comparative good practices, Ethiopia may need to have two types or orders of priorities: the first can be applicable with higher flexibility during the rainy season from June to August, and the other can apply during the other seasons (September to May). This is necessary because there is seasonal fluctuation in water volumes thereby affecting the availability and reliability of water resources to fully meet the demands of users.

Under some national laws, there are different mechanisms of setting priorities. The requirement of permit or water access licenses is one of the legal mechanisms to administer and allow water for use in order of priorities. ${ }^{236}$ In Canada, the 1996 Water Act provided that the right holder of the 'deemed' licenses will continue to divert water in accordance with the 'priority number of the deemed license' and the 'terms and conditions of the deemed licence and the Act'. ${ }^{237}$ The requirement to divert water is based on the priority number.

The other mechanism of setting priorities is through the designation of water uses not required for water use permits or licenses. The South African National Water Act can be taken as an example. It states that only two categories of use can be carried out without a license and these are the 'reasonable domestic use, domestic gardening, animal watering, fire-fighting and recreational use'; and the 'continuation of an existing lawful water use'. ${ }^{238}$ As it is discussed above, the FDRE Water Resources Management Proclamation states types of water use that are exempted from permit similar to the South African one, but it lacks clarity and it is partly different regarding the types of exempted uses. For instance, reasonable use is linked with domestic use as standard for water use.

There are some instances where states give express orders of priorities. For example, the Spanish Water Law Act 29/1985 requires 'Basin Hydrological Plan' which is the basis for setting 'development and management' of priorities. ${ }^{239}$ It strikes "an appropriate balance between the needs of societies to use water and the protection of the environment". 240 Where two applicants simultaneously request for permits or licenses, the law states eight priorities, as a solution in their order, by which the authorities may decide the tiers of

${ }^{236}$ Hodgson, supra note 3, p, 50. According the Water Management Act 2000 of New South Wales and Australia, they have automatically converted to water access licenses in new legislations.

${ }^{237}$ Ibid

${ }^{238}$ Id., the second type of use must have taken place within two years and be registered for verification after the authority decides the use should be continued.

${ }^{239}$ Id., cited Art 65 of the Water Law. In general, the legislations requiring States to prepare and develop plan are stated accordingly: Spain 1985, Italy 1989, Morocco 1995, South Africa 1998, Uganda 1995, South Australia (Australia) 1997 and Texas (USA) 1997. These are taken as best lessons to European Union member states.

${ }^{240}$ Ibid. 
priority: (1) drinking water supply, (2) irrigation of land and agricultural uses, (3) industrial uses for electricity production, (4) other industrial uses, (5) aquaculture, (6) recreational uses, (7) navigation and water transportation, and (8) other uses. ${ }^{241}$

Spain's experience is relevant to Ethiopia, and due attention should be given to lessons that can be drawn from such practices in view of the water scarcity for several years. The Global Water Forum has stated that Spain is facing water scarcity due to high demand of water by its population and lack of effective and efficient utilization of water. $^{242} 80 \%$ of Spain's water is consumed for agriculture. ${ }^{243}$ Spain's experience can also complement the reasons for the application of both standards because the plans and conditions for inter-basin transfers and the possibility of foreseeable changes in the uses can be taken conceptually as the manifestations of both reasonable use and beneficial use standard tests respectively. Moreover, Spain's water law clearly states 'rationality' as a standard test. ${ }^{244}$ Act $29 / 1985$ of the Spanish water law states the need to conserve water resources and requires private individuals to pursue rational use of water resources. ${ }^{245}$

In general, appropriate water allocation results in more socially and economically beneficial use of resources and protection of the environment. ${ }^{246}$ Beneficial use is also considered as appropriate where a specific use is prioritized by the public policy of a given state. ${ }^{247}$ Within this ambit, water requirements for ecological functioning and social purposes should be regarded as priority under any legal and strategic process through 'automatic allocation'. 248

${ }^{241}$ Id., citing Art 65 of the Water Law.

${ }^{242}$ Global Water Forum, (2015) 'Current and Future Challenges In Water Management In Spain', available at <http://www.globalwaterforum.org/2015/04/20/current-and-futurechallenges-in-water-resources-management-in-spain/> Accessed on August 14, 2016. There is over exploitation of underground water and led to 'acquifer salinization'. Experts predicted, "....experts on climate change are indicating that in a 50 years time horizon Spain will have less water and it will be more poorly distributed."

243 Ibid.

${ }^{244}$ Antonio Embid (2002) 'The Evolution of Water Law and Policy in Spain', International Journal of Water Resources Development, 18:2, 261-283.Citing Articles 58.4 and 71.2 of the water law.

${ }^{245}$ Id., p, 265.

${ }^{246}$ Wurbs et al, supra note 234, p. 10.

${ }^{247}$ See Richard C. Ausness, (1978) 'Water Use Permits in a Riparian State: Problems and Proposals', Kentucky Law Journal, Vol 6, pp 197-198. Citing McGill v. Card-Adams Co., 47 N.W.2d 912 (Neb. 1951); Note, 'Acquisition of the Right to Use Water', 29 TuL. L. REV. 554 (1955). 'Civilian Tradition and Modern Practice', Louisiana Law Review, Volume $21 \mid$ Number 4.

${ }^{248}$ See Quesne \& Heyden, supra note198, p. 10. 
The status of automatic allocation (as a priority for 'social purposes' under the Ethiopian water law) may be partly related with the priority given to domestic uses. For instance, national drinking water policies or strategies are expected to recognize specific provisions for vulnerable and marginalized groups and ascertain equitable water allocation. ${ }^{249}$ But, the potential priority through automatic water allocation for 'ecological functioning' is not clearly stated under the Ethiopian water law. This may hinder the pursuance of the stronger version of sustainable development. Priority options and possibilities should thus be systematically applied both and/or beyond the standard tests, as discussed in the following section.

\subsection{Systematic and optional application of both standards in prioritizing use rights}

Standards address the risks of potential water crisis associated with "an overall scarcity of usable water of good quality" as compared with the need and demand of the society. ${ }^{250}$ It is possible to formulate clear, sufficient and comprehensive standardized options to deal with water use problems.

\section{a) Option one}

The law can embody exhaustive rank of uses based on Ethiopia's current problem-situation analyses and policies. As stated earlier, such ranking is embodied in water laws such as Spain's and in the water right modelling project in USA. ${ }^{251}$ This was established by monthly 'simulation' and supported by set of fully characterized priority rights. ${ }^{252}$ These sets hold identified number of users with specific right in every set. ${ }^{253}$ Each right set was limited from making "diversion in stream flow, hydro power, and storage refilling" but it was allowed to use to the extent of available water and storage capacity limited for consideration of other junior rights. ${ }^{254}$ These schemes avoid one of the priorities acquired in the prior appropriation doctrine because the numbers of appropriators that requested for permit were proliferating. The ranking of priorities establishes priority to certain right, but this is meanwhile accompanied by limitations to avoid the increasing number of requests for permit. ${ }^{255}$ This can be taken as a

${ }^{249}$ See Luh et al., supra note 146, p. 664.

${ }^{250}$ See, for example Jain \& Singh, supra note 228.

${ }^{251}$ See. Wurbs, supra note 234, p. 238

${ }^{252}$ See, for example, Zemede et al, supra note 1, p. 2 Even the consortium has included the need of simulation "....simulate dynamic hydrological-ecological-crop interactions under different climate and development scenarios...."

253 See Wurbs, supra note 234, p. 238

254 Ibid.

${ }^{255}$ Id., p, 239. The priority scaling model stated conveniently adjusted specific priorities; but it is recommended municipal rights could be given prior to all agricultural right in a 
good model to Ethiopia owing to the need for clearly stated set of rights or elements within the domestic use or other top priorities. Moreover, it can be made flexible where there is any incompatibility based on the standards. The flexibility can be periodical because the availability and reliability of water have impact on the order of priority. ${ }^{256}$

\section{b) Option two}

This option relates to putting the reasonable use standard among the relatively high ranked categories of uses in each rank. At the same time, it is possible to put restrictions in the relation of each category by testing whether the prior user has used the water for beneficial use as compared to the next user. Harmonious use right will be established among the intra-users within a specific order because applying the reasonable use as a standard test creates equitable, efficient and sustainable relations of users within a given order or set. The beneficial use test helps to avoid the potential conflict of different use rights of categories or orders of users ranked in priorities. For instance, the law may prioritize irrigation use as one category followed by industrial uses. Still the reasonable use will be tested among the users within the category of irrigation to create harmonious, reasonable and equitable use of water.

The supervising body still needs to test whether or not the reasonably or equitably shared water is being used for beneficial purpose. The law is expected to define what constitutes beneficial use of water in irrigation, or it may be decided on a case by case basis. This experience is similar with the 1998 South African Water Act. The law was accompanied with two tenets so "... that water is allocated equitably and used beneficially in the public interest, while promoting environmental values". ${ }^{257}$ The law could also embody environmental values as a standard beyond the common standard tests.

Ethiopia's water law is expected to balance and prioritize where there are different categories of uses such as irrigation use, industrial use, commercial use or any other use from a given water resource. ${ }^{258}$ To avoid water grabbing, wastage or water crisis, the law is expected to incorporate the beneficial use of water to the most reasonably prioritized uses. Good practice in this regard is Act 29/1985 of Spanish Water Law which embodies the 'rationality' standard with a view 'to conserve' water resources. ${ }^{259}$ Likewise, Ethiopian law is expected to

given period. The water demand of upper stream and downstream is possible to be met without regard to order of priorities. Emphasis added. Since specific volume of water is allocated against the need of each order of priority, it has impliedly stated beneficial use.

${ }^{256}$ Ibid.

${ }^{257}$ Hodgson, supra note 3, p. 88

${ }^{258}$ See FDRE Water Resources Management Regulation 115/2005, Art 2(6).

${ }^{259}$ Antonio Embid, supra note 244, p. 265. 
clearly state the beneficial use of every set of right unless there is a need to allow variation.

\section{c) Option three}

The law can in principle allow beneficial use of any water resource in line with public policy. ${ }^{260}$ Under this option, there may not be the need for ranking relative uses, and the law can rather give priority for the most reasonable uses or top priorities thereby openly allowing water use for beneficial purposes. This option is more dependent on high availability and reliability of water to secure relative demands of water. ${ }^{261}$ It is relatively open with the need to encourage users for beneficial purposes. The law is expected to narrowly or broadly define the types of uses as beneficial ones in line with public policies, programs, development agenda etc. Moreover, the beneficial users are expected to keep and safeguard the equitable utilization of water resources. As discussed above, equitable utilization is broader and may include the reasonable use since a given use of water may be reasonable but it may not be equitably shared among users. ${ }^{262}$ The law may thus test whether a specific use is reasonable use through assessments on water utilization. The assessments may even require withdrawal of water uses for consumption purposes so as to keep the equitable utilization of water to other disadvantaged users. ${ }^{263}$

International water law and customary practice can serve as examples. The Helsinki rules and the UN convention stipulate that a given state sharing international water resources may use "a reasonable and equitable share in the beneficial uses of the waters of an international basin". ${ }^{264}$ This shows the application of triple standards in international water law: reasonable use, equitable share and beneficial use of water. This not only prevents the abuse of rights but also addresses issues of potential conflict. Therefore, the conceptual and normative frameworks of the standard tests and the comparative experience in this regard enable Ethiopia to draw the best lessons toward prioritizing use rights and effectively addressing problems in domestic water use.

${ }^{260}$ See 29 Tul. L. Rev. 554, supra note 247, pp. 1954-1955 available at http://heinonline.org

${ }^{261}$ See Wurbs et al. supra note 234.

${ }^{262}$ See Jeanne Luh et al, supra note 146, See for example, Deya Roy (2012) 'Negotiating marginalities: right to water in Delhi' Urban Water Journal, (Center for Studies in Science Policy, Jawaharlal Nehru University, India) 10:2, 97-104.

${ }^{263}$ See Jeanne Luh, supra note 146, p.663. It is stated "... that the term "equity" refers to substantive equality." Hypothetical equity index was framed.

${ }^{264}$ See The Helsinki Rules on the Uses of the Waters of International Rivers, Report of the Committee on the Uses of the Waters of International Rivers (London, International Law Association, 1967) see also Art 5 and Art 21(2) of the UN convention stating "equitable and reasonable utilization" and "beneficial purpose" respectively. 


\section{Conclusion}

Ethiopia's water policies and laws do not embody exhaustive orders of relative priorities of water use rights. Some of the principles on water use priorities, permits and exemptions are not specific, clear and sufficient. The limitations encourage illegal water captures and wastage of water thereby enhancing risks toward water crisis. ${ }^{265}$ First, the law gives priority only to domestic use. ${ }^{266}$ Second, it embodies priority rights through the prior-appropriation of water. Third, the law exempts some uses from permit which may be considered as priorities if they are prior-appropriations. The law does not state any standard test on how priorities that are established are accommodated. The potential divergence and convergence among competing claims of priority is left unaddressed under the law.

For example, prior-appropriators who have already established water use rights through seniority can encounter competing claims that are made by the domestic users who need to use the same scarce water resource. ${ }^{267}$ Moreover, the priority that users who are exempted from seeking permit have as compared to domestic users and prior-appropriators is unregulated. The law does not also state the procedures of providing permit where two appropriators apply simultaneously requesting for permit to establish priority. In general, there is no clear and sufficient standard on how the responsible organs may give permits by assuring priorities. Therefore, the law must embody both and/or additional standard tests. It should also ensure their clear, sufficient, feasible and harmonious application.

The law has allowed some uses to be appropriated without any permit. ${ }^{268}$ It does not, however, state orders of priority among water uses that are exempted from seeking permit. The status of their priority in relation with domestic use, and the priorities established through prior-appropriations are not regulated under the law. These specific categories of uses are inherently similar to the domestic use but the law does not put them under the definition of domestic use. Even though some of the exempted uses are similar to domestic uses and in spite of an illustrative definition of domestic use, the intention of the legislature

${ }^{265}$ See, for example, Sharad K. Jain \& Vijay P. Singh, supra note 228, p. 231. Water resources management is "... characterized by policies that are unsustainable from economic, social or environmental perspectives." Water is taken as free good not as economic good.

${ }^{266}$ See FDRE Water Resources Management Proclamation 197/2000, Art 7(1).

${ }^{267}$ See Id, Art 7(2), Art (12) states activities not requiring permit.

${ }^{268}$ See FDRE Water Resources Management Proclamation 197/2000, Art 12 (1) ('a' and 'b') 
seems different since they are stipulated under two separate provisions. ${ }^{269}$ This may lead to water grabbing and wastage of water.

The systematic standardization of water use rights through the permit system may entail positive or negative impact on the types of priorities. ${ }^{270}$ It may help as a tool in testing and assessing the sustainability of prospective water use. It may also be useful in examining the impact on the prior water users in light of the purpose, location and duration of the proposed use stated in their proposals. ${ }^{271}$ However, unreasonable regulatory interference may occur where the concerned organ did not predict the potential impact of water use on other prior users.

The concerned organs are in favour of giving priority by issuing permit to investors even if the proposed water source is being used by the exempted users, prior appropriators or domestic users. ${ }^{272}$ This violates the implied application of the reasonable use test and it implicitly redefines the notion of beneficial use as water use for investments or for enhanced economic gains. Under such conceptions, the economic benefits are the predominant aspects of focus and all social benefits are subsumed in the economic benefits. There is no clear demarcation of both benefits. The power of deciding benefits and ownership of water under such settings belong to the state.

It is to be noted that the term beneficial use does not avoid vertical and horizontal conflicts among users. As a result, the law may not address water captures and water wastage by solely applying the beneficial use standard. It is thus necessary to have express provisions of both standards under water use right priorities based on 'multi-criteria' analyses. ${ }^{273}$ To this end, the law should embody relatively exhaustive rank or order of priority. ${ }^{274}$ The concerned organs

${ }^{269}$ See FDRE Water Resources Management proclamation 197/2000, Art 2(2 ) and read cumulatively with Art 12(1) ('a' and 'b').

${ }^{270}$ Emphasis added. Priority established without any condition under the law and priority right acquired through prior appropriation from others.

${ }^{271}$ See FDRE Water Resource Management Proclamation 197/2000, Art 13(2). It states "An application for water use, release or discharge of waste, and waterworks construction permits shall be submitted to the supervising body." The application is also required to include detailed information of the use.

272 See Mastewal Y., supra note 112.

${ }^{273}$ See Zemede et al, supra note 1, p. 2. The consortium has put the need on deliberative engagement of stakeholders and multiple criteria as a base for analysing the situation and giving priority especially for the poor population since its well-being depends on "water based eco-system."

274 See, for example, Art 1228 to Art 1256, of the 1960 Civil Code of the Empire of Ethiopia. It gives the priority to communal use in principle, domestic use (absolute priority) from "....water on, below, running through or bordering....", then irrigation use but shall not affect domestic use, industrial use but be "...bordered or crossed by 
have to exert deep and comprehensive cross-sectional policy analyses to bring equitable, optimal, efficient and effective utilization of water resources. ${ }^{275}$ However, these potential policy-based priorities should not negatively affect the human right to water. ${ }^{276}$ Moreover, the reasonable use and/or the beneficial use should manifest equitable utilization, rational use and equitable governance of water. Above all, reasonableness for priorities has to be assured to specific categories of uses after examining their negative impact.

Meanwhile, the equity approach can be applied in distributing and allocating the share of water resource. ${ }^{277}$ Therefore, the relative and exhaustive orders of priorities should be seen against the availability and sustainability of water resources. ${ }^{278}$ The demarcations, synergies, characterization, clarity, sufficiency and comprehensiveness of the prioritizing standard tests have to be considered and embodied under the relevant policy directions and water laws. The reasonable use, beneficial use, and other potential standard tests should accommodate and regulate the intra and inter-relation of users' interests. They have to be mainstreamed with relevant laws and policies of the country, and should be flexible and accommodative of the diversified and multiple socioeconomic activities existing across the country.

Generally, the policy has to embody priority on water use rights since the current distribution of water may not be sufficient to accommodate the demands of different orders of priorities. The standards have to be applied in a bottom-top approach to bring equitable, efficient and effective water resource utilization of a particular community. The standards should not only reinforce equitable utilization but 'equitable provision' to manifest equitable allocation of water. ${ }^{279}$ The law has thus to be amended in order to promote relative orders of priorities supported by standards that facilitate the attainment of the 'highest social and economic benefits' of water.

water...", hydraulic power. Anyone who is not crossed or bordered by water may apply to court to construct an aqueduct. The special laws are expected to regulate issues of fishing and navigation.

275 See The FDRE Water policy. It may be ranked as domestic use, agricultural use, industrial use, commercial use etc respectively since the agriculture is put as an input for the industrialization.

${ }^{276}$ See Antonio Embid Irujo (2007), supra note 197.

277 See Jeanne Luh et al, supra note 146, p. 663.

${ }^{278}$ See Wurbs, supra note 234. See also, Antonio Embid Irujo, supra note 197, see also, Klass and Huang, supra note 24.

${ }^{279}$ See for example, Alan H. Conley and Desmond C. Midgley, (1988) 'National Water Management In the Republic of South Africa - Towards a Consultative Partnership with Diverse Users In a Semi-Arid Country', Journal of Hydrology, (Department of Water Affairs, P/Bag X313, Pretoria 0001 (South Africa), 100, pp, 473-487. 